\title{
Global patterns and drivers of tidal marsh response to accelerating sea-level rise
}

Neil Saintilan ( $\square$ neil.saintilan@mq.edu.au )

Macquarie University

Katya Kovalenko

University of Minnesota-Duluth

Glenn Guntenspergen

US Geological Survey

Kerrylee Rogers

University of Wollongong https://orcid.org/0000-0003-1350-4737

James Lynch

National Parks Service

Donald Cahoon

USGS https://orcid.org/0000-0002-2591-5667

Catherine Lovelock

University of Queensland https://orcid.org/0000-0002-2219-6855

Daniel Friess

National University of Singapore

Erica Ashe

Rutgers University

Ken Krauss

U.S. Geological Survey https://orcid.org/0000-0003-2195-0729

Nicole Cormier

Macquarie University

Tom Spencer

University of Cambridge https://orcid.org/0000-0003-2610-6201

Janine Adams

Department of Botany, Nelson Mandela University, South Africa

Jacqueline Raw

Nelson Mandela University

Carles Ibanez

EURECAT

Francesco Scarton

SELC

Stijn Temmerman 
University of Antwerp

\section{Patrick Meire}

University of Antwerp https://orcid.org/0000-0003-2599-5350

\section{Tom Maris}

University of Antwerp

\section{Karen Thorne}

US Geological Survey

John Brazner

Department of Natural Resources

\section{Gail Chmura}

McGill University https://orcid.org/0000-0001-7163-3903

\section{Tony Bowron}

St Mary's University

\section{Vishmie Palepitiya Gamage}

Macquarie University

\section{Physical Sciences - Article}

Keywords: Fisheries, Coastal Protection, Biodiversity Conservation, Carbon Sequestration, Sediment Accumulation, Shallow Subsidence, Accretion Rate, Tidal Range

Posted Date: April 26th, 2021

DOI: https://doi.org/10.21203/rs.3.rs-363398/v1

License: (c) (i) This work is licensed under a Creative Commons Attribution 4.0 International License. Read Full License 
1 Global patterns and drivers of tidal marsh response to accelerating sea-level rise

2

4

5

6

7

*Saintilan, Neil, Department of Earth and Environmental Sciences, Macquarie University, Sydney, Australia.neil.saintilan@mq.edu.au

Kovalenko, Katya E., Natural Resources Research Institute, University of Minnesota-Duluth, , USA. philarctus@gmail.com,

Guntenspergen, Glenn, United States Geological Survey, USA.glenn_guntenspergen@usgs.gov

Rogers, Kerrylee, School of Earth, Atmospheric and Life Sciences, University of Wollongong, Australia. kerrylee@uow.edu.au

Lynch, James C., National Park Service, Washington DC, USA. James_lynch@nps.gov

Cahoon, Donald R. United States Geological Survey, USA. dcahoon@usgs.gov

Lovelock, Catherine, E., School of Biological Sciences, The University of Queensland, Australia. C.lovelock@uq.edu.au

Friess, Daniel A., Department of Geography, National University of Singapore, Singapore. Dan.friess@nus.edu.sg

Ashe, Erica, Department of Earth and Planetary Sciences, Rutgers University, USA. ericaashe@gmail.com

Krauss, Ken W. US Geological Survey, Wetland and Aquatic Research Center, USA. kraussk@usgs.gov

Cormier, Nicole, Department of Earth and Environmental Sciences, Macquarie University, Sydney, Australia.nicole.cormier@hdr.mq.edu.au

Spencer, Tom, Cambridge Coastal Research Unit, Department of Geography, Cambridge University UK, ts111@cam.ac.uk

Adams, Janine, DSI-NRF Research Chair in Shallow Water Ecosystems, Institute for Coastal and Marine Research, Department of Botany, Nelson Mandela University, South Africa. Janine.adams@mandela.ac.za

Raw, Jacqueline, DSI-NRF Research Chair in Shallow Water Ecosystems, Institute for Coastal and Marine Research, Department of Botany, Nelson Mandela University, South Africa. Jackie.raw33@gmail.com

Ibanez, Carles, ${ }^{1}$ EURECAT, Department of Climate Change, Catalonia, Spain. ${ }^{2}$ IRTA, Program of Marine \& Continental Waters, Catalonia, Spain.carles.ibanez@eurecat.org

Scarton Francesco.W., SELC, Italy. scarton@selc.it

Temmerman, Stijn, Ecosystem Management research group, University of Antwerp, Belgium. Stijn.temmerman@uantwerpen.be

Meire, Patrick, Ecosystem Management research group, University of Antwerp, Belgium. patrick.meire@uantwerpen.be 
37 Maris, Tom, Ecosystem Management research group, University of Antwerp, Belgium. tom.maris@uantwerpen.be

39 Thorne, Karen, United States Geological Survey, USA. kthorne@usgs.gov

40 Brazner, John, Nova Scotia, Department of Natural Resources. John.Brazner@novascotia.ca

41 Chmura, Gail L., Department of Geography, McGill University, Canada. Gail.chmura@mcgill.ca

42 Bowron, Tony, Saint Mary's University, Canada. Tony.bowron@gmail.com

43 Palepitiya Gamage, Vishmie, Macquarie University. Australia. vishmiesachinthanee.palepi@students.mq.edu.au

45

46

47

48

49

50

51

52

53

54

55

56

57

58

59

60

61

62

63

64

65

66

67

68

69

70

71

72

73

74

75

76

77

78

79

80

81

82

83

*corresponding author 
84

85

86

87

88

89

90

91

92

93

94

95

96

97

98

99

100

101

102

103

104

105

106

107

108

109

110

111

112

113

114

115

116

117

$\underline{\text { Summary Paragraph }}$

The vulnerability of the world's tidal marshes to sea-level rise threatens their substantial contribution to fisheries, coastal protection, biodiversity conservation and carbon

sequestration. Feedbacks between relative sea-level rise (RSLR) and the rate of mineral and

89 organic sediment accumulation in tidal wetlands, and hence elevation gain, have been

00 proposed to ameliorate this risk. Here we report on changes in tidal marsh elevation and

91 shoreline position in relation to our network of 387 fixed benchmarks in tidal marshes on four

2 continents measured for an average of 10 years. During this period RSLR at these marshes

3 reached on average $6.6 \mathrm{~mm} \mathrm{yr}^{-1}$, compared to $0.34 \mathrm{~mm} \mathrm{yr}^{-1}$ over the past millenia. While the

4 rate of sediment accretion corresponded to RSLR, the loss of elevation to shallow subsidence

5 increased in proportion to the accretion rate. This caused a deficit between elevation gain and

96 RSLR which increased consistently with the rate of RSLR regardless of position within the

9 tidal frame, suggesting that long-term in situ tidal marsh survival is unlikely. While higher

98 tidal range $(>3 \mathrm{~m})$ conferred a greater stability in measures of shoreline change and vegetation

9 cover, other regions showed a tendency towards instability and retreat.

101

2

103

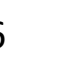

7

(1)

10




\section{Main Body}

Tidal marshes are amongst the most vulnerable of the world's ecosystems. Throughout human civilisation tidal marshes have been reclaimed for agriculture and settlement, and the pace of loss has accelerated in concert with burgeoning coastal populations on all inhabited continents over the past century ${ }^{1}$. To this pressure has been added the threat of accelerating sea-level rise. As tidal marshes occur within tightly defined elevation ranges relative to mean sea level, they are sentinel ecosystems at the forefront of climate change impact. Their potential loss with sea-level rise threathens a range of ecosystem services valued at $\sim \$ 27$ trillion per year ${ }^{2}$, extending to fisheries production, recreation, coastal protection, water quality enhancement and carbon sequestration.

Sea-level rise can lead to in situ marsh loss through three mechanisms: landward retreat, internal expansion of ponds and channels, and loss of marsh surface elevation relative to mean tide level ${ }^{3}$. The fate of tidal marshes under accelerating sea-level rise will be determined by opportunities for landward retreat, but also by the capacity of tidal marshes to gain elevation through processes of vertical accretion (the accumulation of mineral sediment and organic matter ${ }^{4}$ ). Feedbacks between the rate of sea-level rise and the vertical development of marsh substrates ameliorates the risk of conversion to unvegetated mudflat. Modelling based on observations from US East Coast marshes has suggested an equilibrium may emerge between the position of a marsh within the tidal frame, plant productivity, root mass development, sedimentation and the elevation of the marsh in response to mean sea$\operatorname{level}^{5}$ (Fig 1) sustained under low rates of RSLR. How widely these controls, and their upper thresholds, operate across marsh sites around the globe, has been a central and disputed question in the regional- to global-scale modelling of tidal marsh responses to projected rates of relative sea-level rise (RSLR, the combination of vertical land movement and sea level change) under climate change ${ }^{6-8}$.

Several factors operating at regional and global scales may influence the efficacy of tidal marsh vertical adjustment to sea-level rise. Tidal range in marshes can vary by two orders of magnitude (less than $10 \mathrm{~cm}$ to more than $10 \mathrm{~m}$ ) influencing susceptibility to drowning under a given rate of $\operatorname{RSLR}^{9}$. Tidal hydrodynamics and river discharge contribute to sediment delivery and accumulation ${ }^{9}$, and these may be modified by flow control structures ${ }^{10}$. Plant productivity is influenced by climate (precipitation and temperature), atmospheric $\mathrm{CO}_{2}$ and 
152

153

154

155

156

157

158

159

160

161

162

163

164

165

166

167

168

169

170

171

172

173

174

175

176

177

178

179

180

181

182

183

184

185

vegetation composition, as is soil organic carbon accumulation and decomposition. The rate of RSLR varies across coastlines and continents, and millennial-scale variability in RSLR may also confer a legacy of soil organic content ${ }^{11}$. Only by sampling across hydrogeomorphic settings and biogeographic gradients can the significance of these factors be clarified, and the consistency of feedbacks between RSLR and position in the tidal frame be determined.

Accurate measures of tidal marsh vertical adjustment in relation to sea level require a fixed benchmark against which elevation gain or loss can be measured. To this end, the Surface Elevation Table - Marker Horizon (SET-MH) method has been developed as a global standard ${ }^{12}$ for monitoring tidal marsh responses to sea-level rise (Fig 1). A benchmark rod is driven into the marsh to form a stable benchmark against which elevation change can be measured. Vertical accretion is also measured at most sites above an artificial soil horizon (e.g., typically white feldspar or sand) introduced at the time of the first reading against the benchmark (Methods). Comparison between the rate of vertical accretion and elevation gain using the SET-MH method and the rate of RSLR measured at local tide gauges has indicated the vulnerability of mangroves across the Indo-Pacific to sea-level rise and the importance of suspended sediment delivery as a control on mangrove substrate accretion ${ }^{13}$. Data from SETMH stations have informed models of wetland resilience to $\mathrm{RSLR}^{6}$, global projections of tidal wetland change in the coming century ${ }^{7,13,14}$, and the influence of vertical accretion on carbon sequestration ${ }^{15}$. However, palaeo-environmental reconstructions have suggested lower thresholds of vertical adjustment than those inferred from modern observations of vertical accretion in tidal marshes ${ }^{16},{ }^{17}$ and mangroves ${ }^{8}$.

\section{SUGGEST INSERT FIG 1}

Here we analyse tidal marsh elevation adjustment in relation to sea-level rise from our network of 387 SET-MH monitoring stations spanning four continents. Vertical adjustment in marsh accretion and elevation at SET-MH stations were monitored for an average of 10.9 years (range 3.5 - 20.0 years) in a network encompassing a broad range of tidal amplitude, geomorphic settings, rates of RSLR and spanning 70 degrees of latitude north and south of the equator. We analyse marsh elevation gain and accretion in relation to candidate predictive variables collected for each site, including position within the tidal frame, modelled suspended sediment concentration in adjacent water bodies, and climate. RSLR was derived 
186

187

188

189

190

191

192

193

194

195

196

197

198

199

200

201

202

203

204

205

206

207

208

209

210

211

212

213

214

215

216

217

218

219

for three time-scales: (1) modelled for each site over century to millennial timescales; (2) calculated from nearest tide gauges over the past 50 years; and (3) calculated from nearest tide gauges over the period of SET measurements at each site (hereafter contemporaneous RSLR). The centuries over which the tidal marshes formed were characteristed by gradually falling sea-level at the southern hemisphere sites, and RSLR at the northern hemisphere sites of less than $1 \mathrm{~mm} \mathrm{yr}^{-1}$ on average (Table 1; Data S1). During the past 50 years, RSLR at these tidal marshes has increased to $4.1 \mathrm{~mm} \mathrm{yr}^{-1}$ per year, and duringthe period of SET observation to an average of $6.6 \mathrm{~mm} \mathrm{yr}^{-1}$, the latter rate consistent with threshold rates for tidal marsh failure and retreat found in the palaeo-stratigraphic record ${ }^{16,17}$.

While SET-MH stations provide high resolution indication of vertical adjustment of tidal marshes to RSLR, they do not provide an indication of lateral changes ${ }^{18}$. Retreating shorelines may provide an important sediment source that subsidises negative feedbacks between vertical adjustment and RSLR ${ }^{19}$. To assess whether vertical adjustment was associated with sediments from retreating shorelines we used SET-MH platforms as a fixed point from which to assess the lateral shoreline retreat or advance and the distance of each SET from the shoreline. The proportion of unvegetated:vegetated habitat (UVVR), an indicator of marsh stability in relation to RSLR ${ }^{20,21}$ was measured within the surrounding hectare of each SET-MH station (Methods).

The network is clustered in regions with distinct tidal and biogeographic characteristics: the microtidal US Gulf Coast containing the delta of the Mississippi River and associated Chenier plain to the west; the North American Atlantic Coast of barrier and embayment estuaries, extending from mesotidal in the south to macrotidal in the Bay of Fundy; the US Pacific Coast with a strong north-south aridity gradient; North Sea macrotidal coastlines; Southern European micro-tidal coastlines of the Mediterranean Sea, and the micro- to mesotidal coasts of both the Australian Pacific Coast and South Africa (Table S1; Data S1). All SET-MH stations were surveyed to the same height datums as local tide gauges, allowing estimation of position within the tidal frame (Methods). We defined this position as dimensionless D, a useful indicator of hydroperiod ${ }^{22}$.

\section{SUGGEST INSERT FIG 2}

\section{Global drivers of tidal marsh vulnerability}


220 Previous modelling has stressed the importance of suspended sediment concentrations in

221 conferring resilience to wetlands subject to $\operatorname{RSLR}^{6,23,13}$ and modelled total suspended

222 sediment, derived from the MERIS satellite, has been used to project tidal wetland responses

223 to RSLR scenarios at a global scale ${ }^{7}$. While total suspended matter (TSM) proved to be an

224 important determinant of accretion rate (Fig S1) at the regional scale (particularly for Europe

225 and Atlantic North America where previous studies have been focussed ${ }^{23}$ ), only 11 percent of

226 global variation in accretion was explained by TSM. Random Forest models suggest the

227 strongest controls on accretion at the global scale are RSLR (both for the past 50 years and

228 contemporaneous), and position within the tidal frame (Fig 3; Fig S1). That is, the accretion

229 rate is a function of tidal inundation depth and duration, and the rate at which this increases

230 with RSLR.

231

232 SUGGEST INSERT FIG 3

233

234 While accretion was the most important control on elevation gain at the global scale $\left(\mathrm{r}^{2}=\right.$

235 0.32, Fig S2) shallow subsidence or expansion (defined as subsidence below the marker

236 horizon but above the base of the SET benchmark pole) is an important mediator of the

237 relationship between accretion and elevation gain ${ }^{24,25}$ (Fig 1). Shallow subsidence was greater

238 at higher accretion rates $(\mathrm{p}<0.0001)$ (Fig 3$)$ and higher RSLR $(\mathrm{p}<0.0001)$. As a result, on

239 average just over half of the sediment accreted above the marker horizon translated into

240 elevation gain, and this proportion tended to decrease with increasing $\operatorname{RSLR}(\mathrm{P}<0.0001)$.

241 This resulted in a rate of elevation gain below the 50-year average RSLR in most regions, and

242 below the contemporaneous RSLR in all regions (with the exception of the Ebro Delta,

243 Spain, where RSLR declined) (Table 1).

245 There is a tendency for wetlands lower in the tidal frame to be increasing in elevation at a

246 higher rate (Fig 3b), as predicted by models ${ }^{5,6}$, though we found this feedback to be biased

247 towards sites close to retreating shorelines (Fig S3). The mean rate of elevation gain in low

248 marshes $(\mathrm{D}>0)$ showing shoreline stability or progradation was $3.06 \pm 3.11 \mathrm{~mm} \mathrm{yr}^{-1}$, similar

249 to the average for the dataset $\left(2.94 \pm 3.86 \mathrm{~mm} \mathrm{yr}^{-1}\right)$. For low marshes where the shoreline was

250 retreating, the rate of elevation gain was higher (Table S3), though still lagging

251 contemporaneous RSLR. Of the 52 SET-MH stations (13\%) with an vertical accretion rate

252 exceeding maximum long-term vertical adjustment inferred from palaeo-stratigraphic studies 
$253\left(\sim 7 \mathrm{~mm} \mathrm{yr}^{-1}\right)^{8,14,16,17}, 81 \%$ were associated with retreating shorelines, and on average just

$25421.83 \mathrm{~m}$ from the shoreline $( \pm 29.52 \mathrm{~m})$, compared to a network average distance to

255 shoreline of $168.32 \mathrm{~m}( \pm 523.3)$. Sites of highest elevation gain $\left(>7 \mathrm{~mm} \mathrm{yr}^{-1}\right)$, had the lowest

256 median projected time to open water conversion, as estimated by both the time to reach

257 minimum survival elevation, and the time for lateral erosion to reach the SET under current

258 rates of retreat (Table S4). The elevation subsidy provided by proximity to eroding shorelines

$259{ }^{20,26}$ does not confer resilience over broader spatial or temporal scales ${ }^{27}$.

260

261

\section{Regional trends in vulnerability}

262 On the Ebro Delta in Spain sea-level stabilised over the measurement period, and here tidal 263 marshes were high in the tidal frame, shorelines were stable, and elevation increasing (Table

264 1). Though RSLR increased in the macro-tidal marshes of the North Sea (Essex, Norfolk, The 265 Wash in the UK; Scheldt estuary in Belgium) and the Gulf of Maine-Bay of Fundy, (Maine,

266 USA; New Brunswick, Nova Scotia, Canada), these were the most resilient in measures of

267 marsh integrity and vulnerability, consistent with theoretical modelling results ${ }^{9,23}$. The

268 marshes were high in the tidal frame, net shoreline accretion correlated with high

269 concentrations of suspended sediment, and the ratio of unvegetated to vegetated marsh

270 (UVVR) was $\sim 0.1$, a measure consistent with marsh stability ${ }^{21}$. The deficit between elevation

271 gain and contemporaneous RSLR (on average less than $1.5 \mathrm{~mm} \mathrm{yr}^{-1}$ ) was small by global 272 comparison.

273

\section{SUGGEST INSERT TABLE 1}

275

276 Our analysis indicated that eastern Australian tidal marshes are relatively stable, exhibiting

277 the lowest UVVR in the network (Table 1). This is likely due to their relatively high position

278 in the tidal frame, stable shorelines and lower RSLR than the global average (Table 1).

279 Mangroves occupy low marsh positions and tidal marsh loss has been associated with a

280 consistent trend of landward encroachment by mangrove over the past seventy years ${ }^{28}$

281 consistent with the increasing hydroperiod within these tidal marshes.

283 Tidal marshes in the barrier and lagoonal estuaries in the Mediterranean (Venice), South

284 Africa and the Atlantic and Pacific coasts of North America were lower in the tidal frame and subject to higher rates of RSLR than in Australia (Table 1). These marshes had a lower proportion of vegetated marsh than is considered stable ${ }^{21}$ and in $83 \%$ of cases are retreating 
287 (Table 1; Data S1). Tidal marsh elevation gain in these settings was comparable with the 50-

288 year average RSLR but not contemporaneous RSLR, against which a pronounced elevation

289 deficit emerges for South African (2.05 $\left.\mathrm{mm} \mathrm{yr}^{-1}\right)$, North American Pacific-coast tidal marshes

$290\left(\sim 5 \mathrm{~mm} \mathrm{yr}^{-1}\right)$, and to a lesser extent North American Atlantic-coast tidal marshes $\left(<1 \mathrm{~mm} \mathrm{yr}^{-}\right.$

$\left.2911^{1}\right)$.

292

293 The most vulnerable marshes in our global network are associated with the Mississippi River deltaic plain. The active delta sites recorded the highest sediment accretion in the global network (13.28 $\left.7.15 \mathrm{~mm} \mathrm{yr}^{-1}\right)$ translating into the highest elevation gain $\left(6.45 \pm 6.09 \mathrm{~mm} \mathrm{yr}^{-}\right.$ ${ }^{1}$ ), yet still $7.73 \mathrm{~mm} \mathrm{yr}^{-1}$ below contemporaneous RSLR. Marshes were already low in the tidal frame, and the ratio of unvegetated to vegetated marsh was the highest in the global network (Table 1). Shorelines adjacent to monitoring sites retreated at a mean rate of $21 \pm 35$ $\mathrm{cm}$ per year. Marshes in the chenier plain to the west of the active delta are even more vulnerable. Chenier plain marsh elevations and position in the tidal frame are close to the lower survival limit of the dominant genus $(\text { Spartina })^{29}$, adjacent shorelines retreated at a mean rate of $66 \pm 102 \mathrm{~cm}$ per year, and the mean deficit between elevation gain and contemporaneous RSLR is $15.95 \pm 4.09 \mathrm{~mm} \mathrm{yr}^{-1}$ (Table 1). Despite having high sediment accretion, marsh elevation gain is still too low to counter the shallow and deep subsidence experienced by Delta wetlands as they respond to contemporaneous RSLR; the sediment accretion experienced during periods of higher legacy sediment erosion from the vast Mississippi River watershed in the past ${ }^{30}$ is no longer sufficient.

\section{Concluding paragraph}

311 Tidal marshes have been subject to relatively low rates of RSLR over the past few millennia, 312 although this is changing rapidly ${ }^{11}$. Our estimation of RSLR trends across the network suggests local RSLR rates increased from $0.34 \mathrm{~mm} \mathrm{yr}^{-1}$ (averaged for the past 1000 years), to

$3144.1 \mathrm{~mm} \mathrm{yr}^{-1}$ averaged over the past 50 years, to $6.6 \mathrm{~mm} \mathrm{yr}^{-1}$ averaged over the period of SET measurement. To maintain their position, rates of accretion in tidal marshes must increase to fill the increasing accomodation space created by sea-level rise. While tidal marshes in our network show increased rates of accretion in situations of higher RSLR and hydroperiod, shallow subsidence also increases under conditions of higher RSLR and sediment accretion, with the result that a strongly linear deficit emerges between RSLR and elevation gain across the network regardless of elevation. Outside of macrotidal settings, this deficit is associated 
321

322

323

324

325

326

327

328

329

330

331

332

333

334

335

336

337

338

339

340

341

342

343

344

345

346

347

348

349

350

351

352

353

354

with a tendency towards shoreline retreat or, in the Australian sites, encroachment by mangrove. Our observations of the extreme vulnerability of the Mississippi River deltaic plain under current RSLR is consistent with the behavour of the delta in palaeo-stratigraphic studies ${ }^{17}$.

\section{Author contributions}

NS, TS, DC and GG conceived the project. KEK led the data analysis. EA contributed GIA modelling. DF contributed MERIS-derived suspended sediment estimates. NS, KR, NC, GG, JL, DC, JA, JR, KEK, TS, DF, TM, PM, ST, CL, KK, GC, JB, CI, FS, KT, JG, EP conducted readings within the SET-MH network and contributed data and interpretation. VG conducted shoreline recession and UVVR measurements. NS drafted the paper and all authors contributed to writing.

\section{Acknowledgements}

We acknowledge the support in South Africa of the NRF/SAEON Elwandle Node; the NRF/DSI Shallow Marine and Coastal Research Infrastructure (SMCRI); the SAEON Elwandle Coastal Biogeochemical Platform. In the UK the UKRI NERC CBESS (NE/J015423/1). Australian SET readings were supported by the Australian Reseach Council FS100100024 and the Coasts and Clean Seas Initiative The DSI/NRF Research Chair in Shallow Water Ecosystems (UID 84375) supported JBA. GG, KK, and DC acknowledge support from the US Geological Survey Climate Research and Development and Ecosystems Programs. ST received financial support from the Research Foundation of Flanders, Belgium (FWO grant nr: G.0600.18N and G.0316.20N). ELA was supported by the U.S. National Science Foundation grants OCE-1702587 and OCE-2002437. JLR was supported by the DSI/NRF (UID: 111963). Alice Yeates contributed to data management. Maria JS Casallas assisted with shoreline change detection. Data for the Mississippi Delta and Mississippi Chenier sites were retrieved from the Coastal Information Management System (CIMS) database (http://cims.coastal.louisiana.gov); related readings and reporting were supported by Coastal Protection and Restoration Authority (CPRA) of Louisiana, 2021, Coastwide Reference Monitoring System-Wetlands Monitoring Data. Data for US Pacific coast funded 
by USGS Western Ecological Research Center..Any use of trade, firm, or product names is for descriptive purposes only and does not imply endorsement by the US Government.

\section{Data availability statement}

The authors declare that all data supporting the findings of this study are available within the paper [and its supplementary information file S1].

\section{References}

1 Davidson, N. C. How much wetland has the world lost? Long-term and recent trends in global wetland area. Marine and Freshwater Research 65, 934-941 (2014).

2 Costanza, R. et al. Changes in the global value of ecosystem services. Global environmental change 26, 152-158 (2014).

3 Fagherazzi, S. et al. Salt Marsh Dynamics in a Period of Accelerated Sea Level Rise. Journal of Geophysical Research: Earth Surface 125, e2019JF005200 (2020).

4 Kirwan, M. L. \& Megonigal, J. P. Tidal wetland stability in the face of human impacts and sea-level rise. Nature 504, 53-60 (2013).

5 Morris, J. T., Sundareshwar, P., Nietch, C. T., Kjerfve, B. \& Cahoon, D. R. Responses of coastal wetlands to rising sea level. Ecology 83, 2869-2877 (2002).

6 Kirwan, M. L., Temmerman, S., Skeehan, E. E., Guntenspergen, G. R. \& Fagherazzi, S. Overestimation of marsh vulnerability to sea level rise. Nature Climate Change $\mathbf{6}$, 253-260 (2016).

7 Schuerch, M. et al. Future response of global coastal wetlands to sea-level rise. Nature 561, 231-234 (2018).

8 Saintilan, N. et al. Thresholds of mangrove survival under rapid sea level rise. Science 368, 1118-1121 (2020).

9 Kirwan, M. L. \& Guntenspergen, G. R. Influence of tidal range on the stability of coastal marshland. Journal of Geophysical Research: Earth Surface 115 (2010).

10 Syvitski, J. P. \& Kettner, A. Sediment flux and the Anthropocene. Philosophical Transactions of the Royal Society A: Mathematical, Physical and Engineering Sciences 369, 957-975 (2011).

11 Rogers, K. et al. Wetland carbon storage controlled by millennial-scale variation in relative sea-level rise. Nature 567, 91-95 (2019).

12 Webb, E. L. et al. A global standard for monitoring coastal wetland vulnerability to accelerated sea-level rise. Nature Climate Change 3, 458-465 (2013).

13 Lovelock, C. E. et al. The vulnerability of Indo-Pacific mangrove forests to sea-level rise. Nature 526, 559-563 (2015).

14 Jankowski, K. L., Törnqvist, T. E. \& Fernandes, A. M. Vulnerability of Louisiana's coastal wetlands to present-day rates of relative sea-level rise. Nature Communications 8, 1-7 (2017).

15 Lovelock, C. E. \& Reef, R. Variable Impacts of Climate Change on Blue Carbon. One Earth 3, 195-211 (2020).

16 Horton, B. P. et al. Predicting marsh vulnerability to sea-level rise using Holocene relative sea-level data. Nature communications 9, 1-7 (2018). 
40117 Törnqvist, T. E., Jankowski, K. L., Li, Y.-X. \& González, J. L. Tipping points of

402

403

404

405

406

407

408

409

410

411

412

413

414

415

416

417

418

419

420

421

422

423

424

425

426

427

428

429

430

431

432

433

434

435

436

437

438

439

440

441

442

443

444

445

446

447

448

449

450
Mississippi Delta marshes due to accelerated sea-level rise. Science Advances 6, eaaz5512 (2020).

18 Mariotti, G. \& Carr, J. Dual role of salt marsh retreat: Long-term loss and short-term resilience. Water Resources Research 50, 2963-2974 (2014).

19 Hopkinson, C. S., Morris, J. T., Fagherazzi, S., Wollheim, W. M. \& Raymond, P. A. Lateral marsh edge erosion as a source of sediments for vertical marsh accretion. Journal of Geophysical Research: Biogeosciences 123, 2444-2465 (2018).

20 Ganju, N. K. et al. Spatially integrative metrics reveal hidden vulnerability of microtidal salt marshes. Nature communications 8, 1-7 (2017).

21 Wasson, K. et al. Understanding tidal marsh trajectories: evaluation of multiple indicators of marsh persistence. Environmental Research Letters 14, 124073 (2019).

22 Kefelegn, H. Mathematical Formulations for Three Components of Hydroperiod in Tidal Wetlands. Wetlands 39, 349-360 (2019).

23 Kirwan, M. L. et al. Limits on the adaptability of coastal marshes to rising sea level. Geophysical research letters 37 (2010).

24 Nolte, S. et al. Measuring sedimentation in tidal marshes: a review on methods and their applicability in biogeomorphological studies. Journal of Coastal Conservation 17, 301-325 (2013).

25 Cahoon, D. R., Day, J. \& Reed, D. The influence of surface and shallow subsurface soil processes on wetland elevation: a synthesis. Current topics in wetland biogeochemistry 3, 72-88 (1999).

26 Coleman, D. J. \& Kirwan, M. L. The effect of a small vegetation dieback event on salt marsh sediment transport. Earth Surface Processes and Landforms 44, 944-952 (2019).

27 Schuerch, M., Spencer, T. \& Evans, B. Coupling between tidal mudflats and salt marshes affects marsh morphology. Marine Geology 412, 95-106 (2019).

28 Saintilan, N., Rogers, K., Kelleway, J., Ens, E. \& Sloane, D. Climate change impacts on the coastal wetlands of Australia. Wetlands 39, 1145-1154 (2019).

29 McKee, K. L. \& Patrick, W. The relationship of smooth cordgrass (Spartina alterniflora) to tidal datums: a review. Estuaries 11, 143-151 (1988).

30 Cahoon, D. R. Estimating relative sea-level rise and submergence potential at a coastal wetland. Estuaries and Coasts 38, 1077-1084 (2015). 
Table 1: Indicators of Regional saltmarsh vulnerability to sea-level rise. Values are means of the number of sites (n) with standard deviation in

457 Unvegetated:Vegetated ratio. Local Relative Sea Level Rise (RSLR) is calculated for the previous 500 years using Glacio-isostatic adjustment modelling; and for 50 years prior to 2021 (RSLR 0-50) and for the period contemporaneous with site SET-MH measurements (RSLR SET period) using tide gauges. Colour coding reflects a tendency for each indicator towards marine (blue) or terrestrial (green) conversion.

460

\begin{tabular}{|c|c|c|c|c|c|c|c|c|c|c|c|c|}
\hline Region & $n$ & $\begin{array}{l}\text { Elevation } \\
\text { above } \\
\text { lower limit } \\
\text { (cm) }\end{array}$ & $\begin{array}{l}\text { Tide } \\
\text { range }(\mathrm{m})\end{array}$ & $\begin{array}{l}\text { RSLR } \\
0-500 \\
\left(\mathrm{~mm} \mathrm{yr} r^{-1}\right)\end{array}$ & $\begin{array}{l}\text { RSLR } \\
0-50 \\
\left(\mathrm{~mm} \mathrm{yr}^{-1}\right)\end{array}$ & 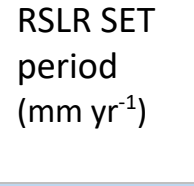 & $\begin{array}{l}\text { Total } \\
\text { Suspended } \\
\text { Matter } \\
\left(\mathrm{mg} \mathrm{l}^{-1}\right)\end{array}$ & $\begin{array}{l}\text { Sediment } \\
\text { Accretion } \\
\left(\mathrm{mm} \mathrm{yr}^{-1}\right)\end{array}$ & $\begin{array}{l}\text { Elevation } \\
\text { gain } \\
\left(\mathrm{mm} \mathrm{yr} \mathrm{r}^{-1}\right)\end{array}$ & 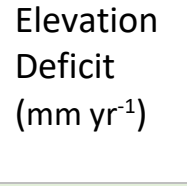 & $\begin{array}{l}\text { Shoreline } \\
\text { trend } \\
\left(\mathrm{m} \mathrm{yr}^{-1}\right)\end{array}$ & UVVR \\
\hline $\begin{array}{l}\text { Bay of Fundy- Gulf } \\
\text { of Maine }\end{array}$ & 23 & $212.0(49.0)$ & $5.61(3.30)$ & $0.67(0.60)$ & $2.13(0.20)$ & 1.11 (3.63) & $12.61(14.2)$ & $2.27(0.73)$ & $0.74(0.91)$ & $-0.61(4.47)$ & $0.02(0.43)$ & $0.17(0.08$ \\
\hline North Sea & 37 & $202.2(51.8)$ & $3.69(0.81)$ & $0.02(0.88)$ & $1.76(0.78)$ & $5.10(4.53)$ & $13.39(4.54)$ & $7.90(4.44)$ & $3.63(3.67)$ & $1.47(5.13)$ & $1.16(2.69)$ & $0.11(0.07)$ \\
\hline Mediterranean & 39 & $47.3(0.31)$ & $0.29(0.17)$ & $0.59(0.17)$ & $2.67(0.79)$ & $-0.98(2.90)$ & $5.43(2.93)$ & $3.01(2.15)$ & $2.12(3.09)$ & $-3.11(3.58)$ & $-0.04(0.18)$ & $0.25(0.18$ \\
\hline $\begin{array}{l}\text { US Gulf Coast: } \\
\text { Mississippi Delta }\end{array}$ & 64 & $1.8(2.5)$ & $0.35(0.01)$ & $0.99(0.00)$ & $9.13(0.0)$ & $14.27(0.38)$ & $9.50(4.62)$ & $13.28(7.15)$ & 6.45 (6.09) & $7.73(6.02)$ & $-0.21(0.35)$ & $0.36(0.22$ \\
\hline $\begin{array}{l}\text { US Gulf Coast: } \\
\text { Mississippi Chenier }\end{array}$ & 33 & $-0.1(7.4)$ & $0.56(0.14)$ & $1.55(0.00)$ & $6.74(0.71)$ & $18.11(2.40)$ & $12.44(9.34)$ & $8.19(3.81)$ & $2.22(3.01)$ & $15.95(4.09)$ & $-0.66(1.02)$ & $0.20(0.29)$ \\
\hline US Atlantic Coast & 68 & $46.7(60.0)$ & $1.25(0.97)$ & $-0.73(3.57)$ & $4.00(1.10)$ & 4.49 (2.57) & $6.40(5.33)$ & $3.78(1.70)$ & $3.15(2.62)$ & $1.00(5.25)$ & $-0.35(0.41)$ & $0.24(0.21)$ \\
\hline $\begin{array}{l}\text { Australian Pacific } \\
\text { Coast }\end{array}$ & 59 & 96.7 (33.2) & $1.27(0.34)$ & $-0.22(0.43)$ & $1.77(0.98)$ & $3.07(0.76)$ & $4.41(4.28)$ & 1.85 (1.04) & $0.87(1.06)$ & $2.20(1.49)$ & $0.00(0.45)$ & $0.04(0.05)$ \\
\hline${ }^{*}$ mangrove boundary & & 33.7 (23.9) & & & & & & & & & $-0.29(0.55)$ & \\
\hline US Pacific Coast & 61 & 74.5 (19.8) & $1.31(0.33)$ & $0.88(0.28)$ & $2.53(1.19)$ & $7.10(5.33)$ & $8.81(9.53)$ & 3.69 (3.03) & $2.26(2.28)$ & $4.18(4.94)$ & $-0.01(0.26)$ & $0.23(0.24)$ \\
\hline South Africa & 15 & 77.7 (41.2) & $1.92(0.35)$ & $-0.54(0.07)$ & $2.12(0.00)$ & $2.73(0)$ & $3.84(0.84)$ & n.d & $0.69(4.32)$ & $3.89(5.77)$ & $-0.08(0.21)$ & $0.32(0.15)$ \\
\hline Global & 387 & $58.4(66.6)$ & $1.40(1.58)$ & $0.34(1.70)$ & 3.80 (2.99) & 6.60 (6.38) & $8.09(7.41)$ & 5.69 (5.57) & $2.94(3.86)$ & $3.66(6.46)$ & $-0.10(0.87)$ & $0.21(0.21)$ \\
\hline
\end{tabular}

461 
462

463

464

465

\section{Figures}

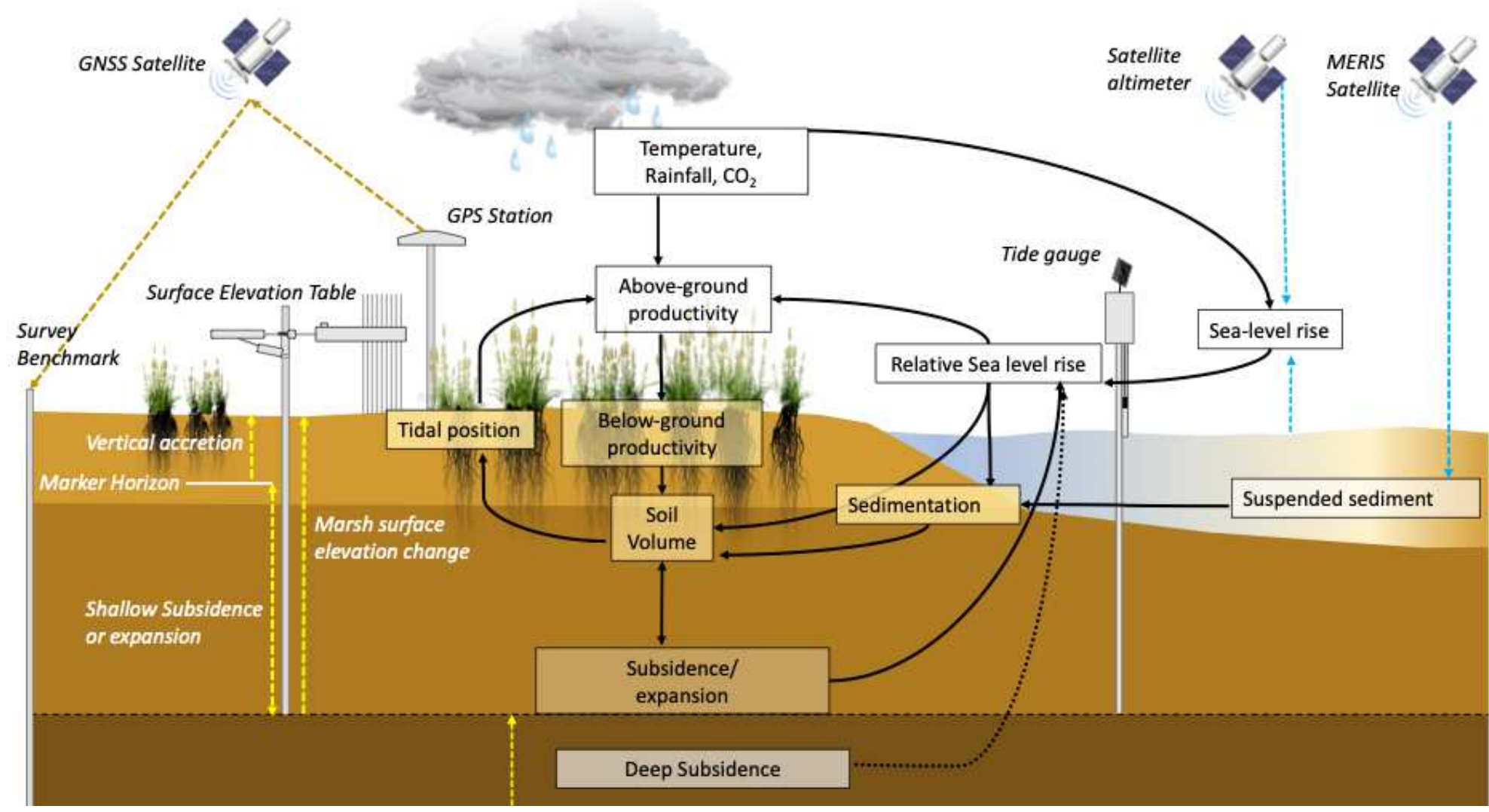



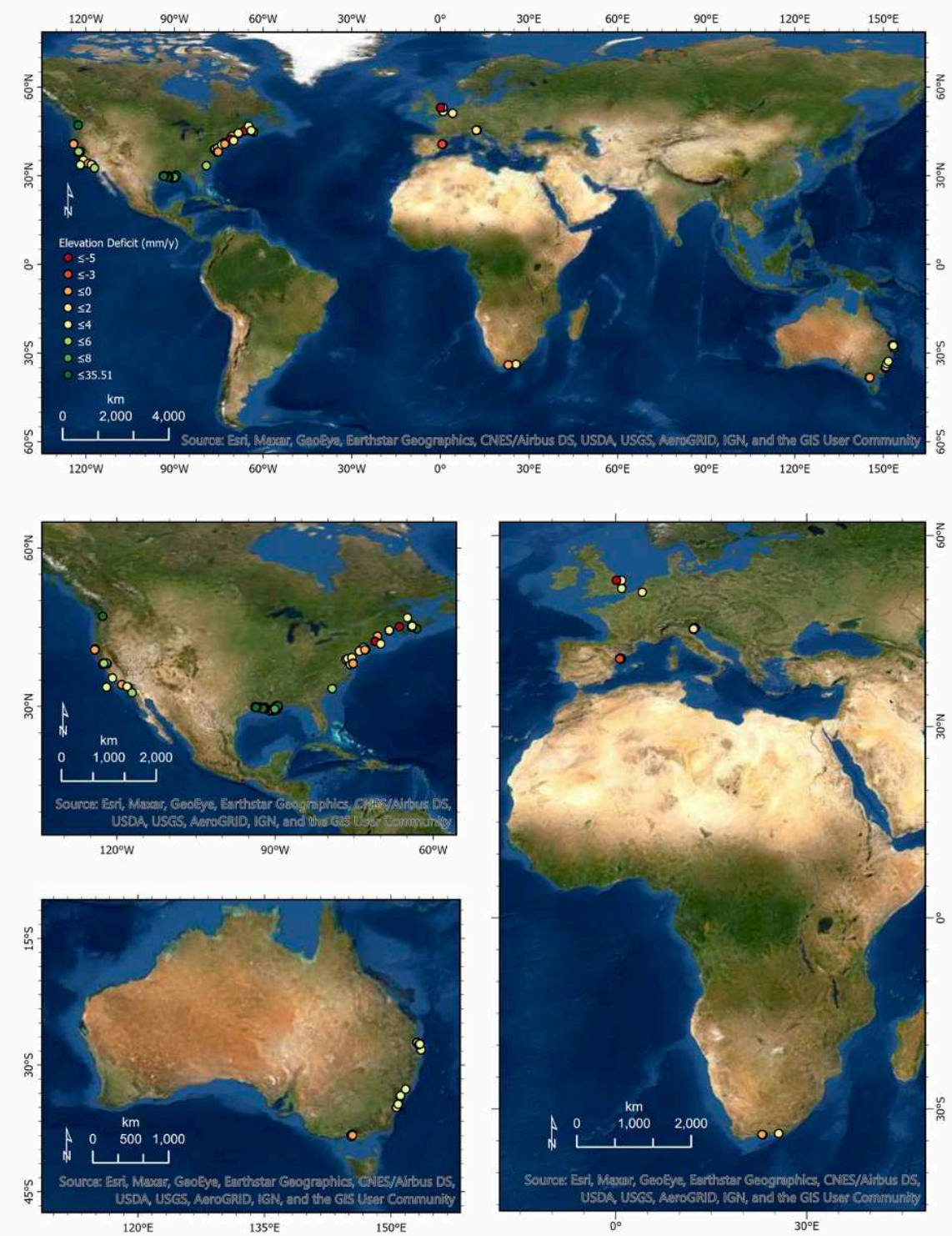

Fig 2: Distribution of tidal marsh SET-MH stations used in the analysis, and deficit between elevation gain and local RSLR. 

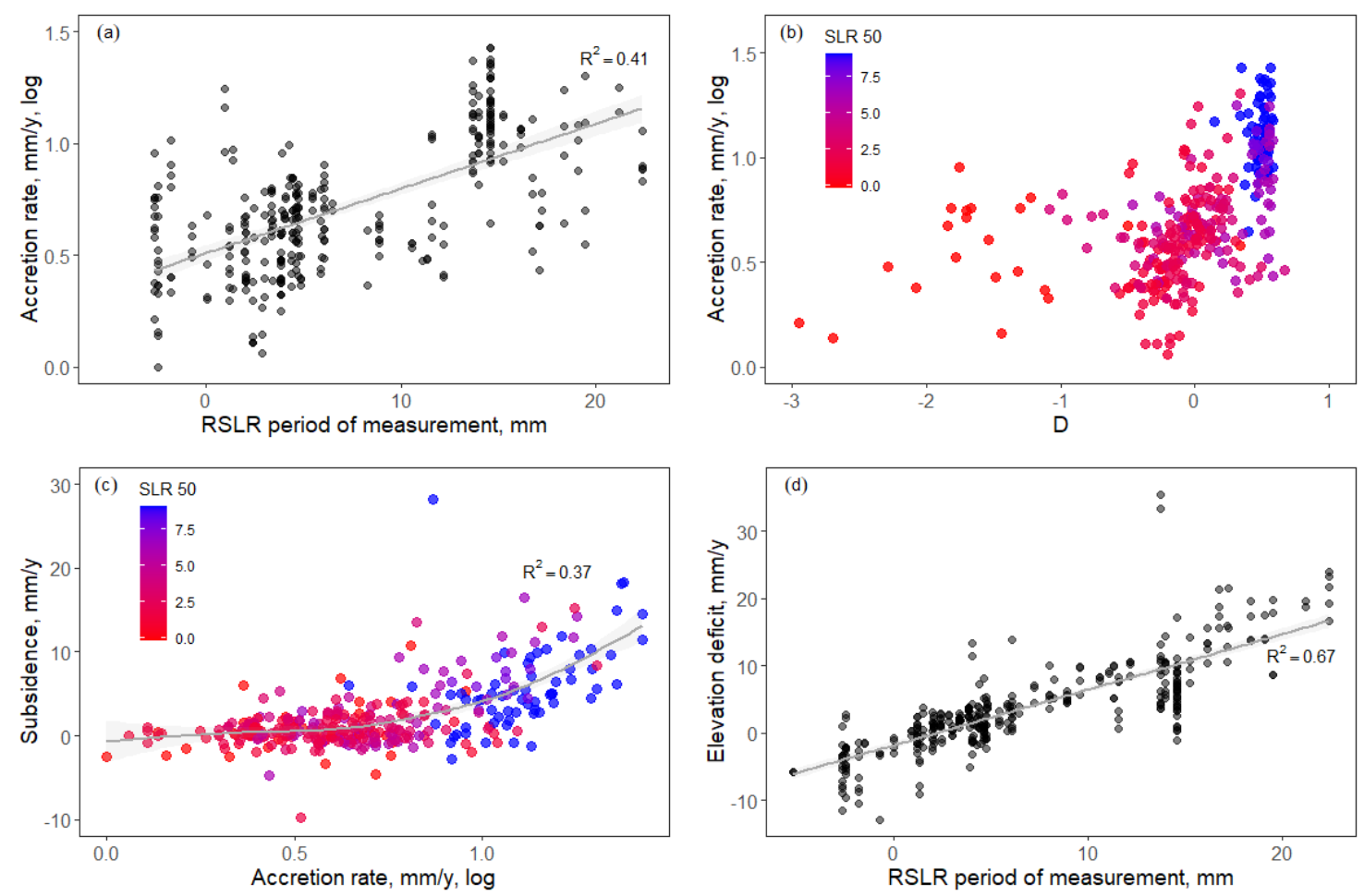

Figure 3: The increasing vulnerability of tidal marshes to RSLR. While accretion increases with RSLR over the same period of measurement (a),

478 and with increasing depth in the tidal plane (b), the rate of shallow marsh subsidence increases with accretion rate (with an upward inflexion as

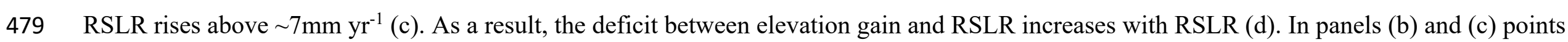
480 are coloured for the 50-year RSLR trend in ${\mathrm{mm} \mathrm{yr}^{-1}}^{-1}$ 


\section{Materials and Methods}

\section{Conceptual Model}

We conceptualise surface elevation trends as a function of elevation gains (through sediment accumulation, and soil volume expansion, including root mass gain) and losses (through sediment erosion, and soil volume losses such as subsidence and compaction). These processes are driven by hydrological, geomorphological and biological processes (Fig 1). Hydrological processes influence the accumulation of sediment through the mechanism of tidal inundation. Tides define the lateral limit of tidal marshes and the space available for accumulation of both mineral and organic material, and accumulation of tidally borne material on marsh surfaces is also a function of inundation depth. Sea-level rise alters the elevation of tides and consequently influences both accommodation space and the rate of sedimentation occurring on marsh surfaces. Geomorphological processes influence the suspended sediment supply, sediment characteristics and the rate of shallow subsidence. Biological processes include the influence of vegetation on sediment trapping and belowground root production, and the influence of microbial decomposition on soil organic matter ${ }^{1}$. Climate (temperature and precipitation) influences biological processes including plant productivity and microbiological activity.

\section{SET-MH network and installation}

The Surface Elevation Table-Marker Horizon $\left(\mathrm{SET}-\mathrm{MH}^{2}\right)$ technique is regarded to be the global standard in measuring wetland responses to sea-level rise in real time ${ }^{3}$. It combines a benchmark rod against which marsh elevation change is monitored (the SET), with an artificial soil marker horizon against which marsh vertical accretion is measured (the $\mathrm{MH})^{4}$ (Figure 1). Prior to installation, a platform is usually constructed to minimise disturbance and compaction. In our network two types of benchmark rod were used: an "original" design consisting of a hollow aluminium pole up to 8 metres in length, and an "rSET" design, consisting of a solid stainless steel rod capable of insertion to greater depths (up to $\sim 30$ metres). In both cases benchmark rods serve as a fixed point against which marsh elevation change is measured. A portable arm is attached to the benchmark at each visitation and supports 9 replicate pins that are lowered to the marsh surface at four fixed compass 
518 directions; measurements of the height of each pin above the portable arm are taken at each

519 visit. At commencement, replicate (3 to 4) marker horizons (feldspar or clay) are laid on the

520 soil surface over $0.25 \mathrm{~m}^{2}$ square plots adjacent to each SET and are subsequently buried by

521 the accumulation of tidally borne sediment and root growth. A shallow core is extracted and

522 the depth of the marker horizon in each replicate plot recorded at each visit. The difference

523 between surface accretion, as measured from cores extracted from the $\mathrm{MH}$, and surface

524 elevation change, as measured using the SET, is a measure of shallow subsidence or

525 expansion occurring between the bottom of the marker horizon and base of the SET

526 benchmark $^{4}$ (Figure 1).

527

528 Our network consists of 387 SET-MH stations in tidal marshes installed using common

529 protocols in 89 locations on four continents (North America, Australia, Europe, South

530 Africa). From this network changes in surface elevation and vertical accretion were

531 determined from repeated measurements occurring across timescales ranging from 3.5 to 20

532 years (average 10.9 years: Data S1), and rates of surface elevation change and vertical

533 accretion were determined at each site. The network consists of seven regional clusters (Fig

534 2), being the Atlantic coast of North America (91 SETs; 23 of which were located in the

535 macro-tidal Bay of Fundy/Gulf of Maine); the US Gulf Coast (97 SETs); the Pacific Coast of

536 North America (61 SETs), the Pacific coast of Australia (59 SETs); the Mediterranean Sea

537 (39 SETs); the North Sea (37 SETs); and South Africa (15 SETs). Tidal marsh SET-MH

538 stations were not included if the length of the measurement record was short and potentially

539 influenced by perturbations (minimum 3.5 years), were not intertidal, where marsh elevation

540 in relation to tidal frame was not known, or where the SET-MH station was associated with a

541 hydrological restoration initiative. Some sites had not recorded accretion but were included in

542 analyses of elevation change. Sites spanned macrotidal settings (greater than $3 \mathrm{~m}$ tidal range:

543 Bay of Fundy, Canada; Gulf of Maine, USA; The Wash, UK) to microtidal settings (less than

5441 metres tidal range: US Gulf Coast; Venice Lagoon) and were evenly distributed between

545 coastlines subject to relatively rapid RSLR ( $>5 \mathrm{~mm} \mathrm{yr}^{-1} ; 119$ SETs), near average global

546 eustatic RSLR (2-5 $\mathrm{mm} \mathrm{yr}^{-1} ; 150$ SETs), and low RSLR ( $<2 \mathrm{~mm} \mathrm{yr}^{-1}$ (114 SETs) (Fig 4)

547 averaged for the past 50 years.

548

549

550

551

\section{Position in tidal frame, elevation capital and time to failure}


552 We measured the elevation (Z) of each SET-MH station in relation to the local height datum

553 using either a real time kinematic GPS or differential GPS, and accessed mean high water

554 (MHW), mean low water (MLW) and mean sea level (MSL) in relation to the local height

555 datum for the nearest tide gauge (Table S2). We calculated tide range as the difference

556 between MHW and MLW. We described position within the tidal frame using

557 "dimensionless d" 5 (D; Equation 1), a metric commonly used in the interpretation of

558 intertidal position ${ }^{6,7}$, and found in a survey of US marshes ${ }^{7}$ to be a useful approximation of

559 flooding duration.

560

561

562

563

$\mathrm{D}=(\mathrm{MHW}-\mathrm{Z}) /(\mathrm{MHW}-\mathrm{MLW})$

564 survive has been termed "elevation capital", and is useful in conceptualising the

565 vulnerability to vegetation die-off of a wetland subject to a deficit between RSLR and

566 elevation gain ${ }^{9,10}$. Vegetation growth range can be normalised across sites of varying tidal

567 range given the consistency of upper range limits in relation to MHW and lower range limits

568 in relation to MSL for tidal marshes. We used the results of a global assessment of marsh

569 lower limits ${ }^{11}$ to relate lowest possible elevation to tidal range (Equation 2)

570 Marsh-tidal flat border $(\mathrm{m})=-108.23 * \log 10(\mathrm{MTR})+163.21$

571 Where MTR $=$ Mean tidal range $(\mathrm{m})$

572 Elevation Capital was calculated as the difference between marsh elevation and the modelled

573 marsh-tidal flat border. Time to failure was calculated as the elevation capital divided by the

574 accretion deficit. We acknowledge the caveat that factors other than elevation may influence the

575 survival of marsh vegetation in the context of high rates of RSLR, including for example the

576 effect of topographic constraints on marsh drainage and hydroperiod ${ }^{12}$. The results are used for

577 the purpose of broad-scale comparisons of vulnerability.

578

579

4. Relative Sea-level rise

580 Contemporary rates of RSLR (for the past 50 years, and the period for each site

581 contemporaneous with SET-MH measures) were obtained from NOAA

582 (https://tidesandcurrents.noaa.gov/sltrends/sltrends.html), or local tide gauges as documented

583 in Table S1. We also considered longer-term (centennial to millennial) rates of RSLR given

584 their possible influence on upper marsh processes. Rates of local and regional RSL change

585 during the Holocene are primarily the result of glacio-isostatic adjustment (GIA), the ongoing 
586

587

588

589

590

591

592

593

594

595

596

597

598

599

600

601

602

603

604

605

606

607

608

609

610

611

612

613

614

615

616

617

618

619

deformational, rotational and gravitational effects on the Earth in response to the redistribution of ice and ocean loads that influences both eustatic and relative sea level. We use a revised numerical simulation of glacio-isostatic adjustment ${ }^{13}$, which adopts the ICE-6G global ice reconstruction from the Last Glacial Maximum (LGM) to the present ${ }^{14,15}$. The GIA calculations are based on a gravitationally self-consistent theory for computing patterns of sea level. The model incorporates time-varying shorelines and the feedback of loadinduced perturbations to Earth's rotation vector ${ }^{16}$. The sea-level calculations are based on a gravitationally self-consistent theory that assumes a spherically symmetric, self-gravitating, Maxwell viscoelastic Earth model and adopts the ICE-6G global ice reconstruction (slightly modified from ${ }^{13}$ ). The elastic and density components of the model are given by the seismically inferred earth model PREM ${ }^{17}$ and the Earth's structure is characterised by three parameters: the lithospheric thickness, $L T$, and upper and lower mantle viscosities denoted by $V_{U M}$ and $V_{L M}$, respectively.

We used an ensemble of 300 combinations of these rheological parameters in the GlacioIsostatic Adjustment (GIA) model to estimate RSL at 500-year periods on a $512 \times 260$ global grid (Data S1). The 300 combinations of parameters included $L T$ from $24-140 \mathrm{~km}, \mathrm{~V}_{\mathrm{UM}}$ from $0.3-2 \times 10^{21} \mathrm{Pas}$, and $\mathrm{V}_{\mathrm{LM}}$ from $3-100 \times 10^{21} \mathrm{Pas}$, where each combination is assumed to be equally likely. We linearly interpolated between grid and time points from these ensemble members to predict RSL rates of change and their uncertainties for each site in this study. Rates of historic change were provided for consecutive 500-year periods from 0500BP (SLR250 in Data S1) to 3500-4000 BP (SLR3750 in Data S1).

\section{Suspended sediments (total suspended matter TSM)}

A remote sensing product that estimates the dry weight of particles suspended in the coastal water column $\left(\mathrm{g} \mathrm{m}^{3}\right)$ was compared to field measurements of vertical accretion, similar to previous studie ${ }^{18,19}$. Data collected by MEdium Resolution Imaging Spectrometer (MERIS) instrument (290-1040 nm) on the ENVISAT satellite, hosted by the European Space Agency $(\mathrm{ESA})^{20}$ were processed and validated through the ESA's GlobColour (downloadable from http://hermes.acri.fr/). TSM data were level-3 processed at $4 \mathrm{~km}^{2}$ resolution in Plate Carrée projection. Data were binned monthly from January to December 2011 (the most recent year of data available), and the mean monthly values were used to generate an annual average TSM product. $85 \%$ of SET sites comprised 11-12 months of TSM data, 10\% of sites 
620

621

622

623

624

625

626

627

628

629

630

631

632

633

634

635

636

637

638

639

640

641

642

643

644

645

646

647

648

649

650

651

652

653

comprised 9-10 months of TSM data, and 5\% of sites comprised 8 months or less of TSM data. At the time of extraction, data were available from 2002-2011, though a previous study has shown that spatial variation in TSM shown in 2011 is representative of spatial variation across the entire time period ${ }^{9}$.

The open-source software BEAM VISAT was used to extract TSM data from the pixel encompassing an SET site (78.4\% of sites), or the closest pixel (21.6\% of sites). For the latter, this was generally the neighbouring pixel, though the furthest TSM pixels (Scheldt Estuary, Belgium) were 6 pixels $(24 \mathrm{~km})$ away from the SET site. GlobColour TSM values are only roughly indicative for variations in TSM locally in the considered marsh sites and may poorly estimate the local-scale resuspension and delivery of sediment in marsh environments.

\section{Climate, vegetation and Geomorphic setting}

Mean annual temperature and mean annual precipitation were sourced from the nearest meteorological station as documented in Table S3. Dry bulk density is the dry weight of both organic and inorganic materials in a sample of known volume, and typically reported as grams per cubic centimeter ${ }^{21}$. We measured the bulk density of the upper $10 \mathrm{~cm}$, the section of profile most likely to correspond to sediment accreted during the period of record. Dominant vegetation was classified to genus level (Data S1), and clustered into the following categories by growth form and habit:

- Spartina (most frequently the dominant genus)

- Short grasses and herbs: Sporobolus, Distichlis, Salicornia, Sarcocornia, Poa, Glaux, Borrichia, Puccinellia, Paspalum, Elymus, Impatiens

- Brackish rushes: Juncus, Schoenoplectus, Phragmites, Cladium, Scirpus, Carex,

- Saltbushes/shrubs: Atriplex, Tecticornia, and a stunted growth form of the mangrove Avicennia

Sites were classified according to the geomorphic units using a typology that defines estuarine settings on the basis of dominance of river, wave and tide energy ${ }^{22}$ : Barrier Estuarine (estuaries sheltered behind sand barriers along wave-dominated coastlines); Riverine Estuarine (sites associated with river systems where fluvial sedimentation is building active deltas); Tidal Estuarine (sites of meso-macro tidal range in which tidal deposition and erosion is a dominant process); Calcareous (sites associated with coral reef 
654

655

656

657

658

659

660

661

662

663

664

665

666

667

668

669

670

671

672

673

674

675

676

677

678

679

680

681

682

683

684

685

686

687

688 barriers); and Marine Embayment (sites protected from oceanic waves by shoreline configuration but for which fluvial influence is minor). Dominant vegetation categories and geomorphic units were used as categorical predictors in the Random Forests analyses (see below).

\section{Shoreline trend assessment and UVVR}

We used Google Earth Engine to locate the position of SET platforms. The platforms were used as a fixed point in the landscape against which to assess shoreline change. The distance between the SET platform and the nearest vegetated shoreline was measured over the period for which available historic imagery corresponded most closely to the length of the SET record. For Australian sites, where mangroves frequently occupy the lower intertidal zone, the distance to the closest contiguous mangrove stand was also measured. Imagery was discarded if high water level or cloud cover obscured the platform or vegetated shoreline. In some cases georectification errors prevented meaningful comparison between images.

Results are shown in Table S1.

The ratio of unvegetated to vegetated marsh (UVVR) has been identified as a useful indicator of marsh stability ${ }^{23,24}$. Stable marshes are more likely to be uniformly vegetated, and the UVVR can provide a snapshot of the status of a marsh on a spectrum to open water conversion. A UVVR of $<0.15$ is characteristic of intact marshes showing little deterioration ${ }^{25}$. We calculated UVVR within a one-hectare perimeter of each SET using the most recent imagery from Google Earth Engine.

\section{Data Analysis}

For each SET, relative pin height was calculated by subtracting baseline pin height from all subsequent readings. Relative pin heights were averaged hierarchically within each SET arm position and then across positions to integrate small-scale variation in surface elevation. The rate of elevation change was then calculated as a linear regression slope for the relationship between the date of measurement and averaged relative pin height. A similar approach was used to calculate accretion rates. Simple and multiple linear regression were used to test relationships between quantitative variables. Generalized additive models (GAM) was used to test the relationship between subsidence and accretion rate. Analyses of variance were 
689

690

691

692

693

694

695

696

697

698

699

700

701

702

703

704

705

706

707

708

709

710

711

712

713

714

715

716

717

718

719

720

721

722

723

724

725

726

727

728

729

used to compare the rate of accretion and elevation gain between retreating and advancing marshes low and high in the tidal frame (D).

RandomForest classification ${ }^{26}$ was used to examine relationships between accretion, elevation change, shoreline retreat, and UVVR and all other predictor variables (Table S1).

RF is a machine learning approach which operates by constructing thousands $(n=10,000)$ of small classification trees, results of which are then tallied across the entire forest. An unbiased estimate of error is obtained at each step internally by using a different bootstrap resample from the original data. Approximately 33\% of observations are used to test each run's performance as the out-of-bag error (OOB). Data compilation, analyses and visualizations were done in $\mathrm{R}$ (version 4.0.2 ${ }^{27}$ ) using tidyr ${ }^{28}$, randomForest $^{29}$ and viridis ${ }^{28}$ packages.

\section{References: Materials and Methods}

1 Krauss, K. W. et al. How mangrove forests adjust to rising sea level. New Phytologist 202, 19-34 (2014).

2 Lynch, J. C., Hensel, P. \& Cahoon, D. R. The surface elevation table and marker horizon technique: A protocol for monitoring wetland elevation dynamics. (National Park Service, 2015).

3 Webb, E. L. et al. A global standard for monitoring coastal wetland vulnerability to accelerated sea-level rise. Nature Climate Change 3, 458-465 (2013).

4 Cahoon, D. R., Reed, D. J. \& Day Jr, J. W. Estimating shallow subsidence in microtidal salt marshes of the southeastern United States: Kaye and Barghoorn revisited. Marine geology 128, 1-9 (1995).

5 Morris, J. T., Sundareshwar, P., Nietch, C. T., Kjerfve, B. \& Cahoon, D. R. Responses of coastal wetlands to rising sea level. Ecology 83, 2869-2877 (2002).

6 Morris, J. T. Competition among marsh macrophytes by means of geomorphological displacement in the intertidal zone. Estuarine, Coastal and Shelf Science 69, 395-402 (2006).

7 Kefelegn, H. Mathematical Formulations for Three Components of Hydroperiod in Tidal Wetlands. Wetlands 39, 349-360 (2019).

8 Cahoon, D. R. \& Guntenspergen, G. R. Climate change, sea-level rise, and coastal wetlands. National Wetlands Newsletter 32, 8-12 (2010).

9 Lovelock, C. E. et al. The vulnerability of Indo-Pacific mangrove forests to sea-level rise. Nature 526, 559-563 (2015).

10 Morris, J. T. et al. Tidal and Hurricane Impacts on Saltmarshes in the Northeastern Coastal and Barrier Network: Theory and Empirical Results. Estuaries and Coasts, 114 (2020). 
730

731

732

733

734

735

736

737

738

739

740

741

742

743

744

745

746

747

748

749

750

751

752

753

754

755

756

757

758

759

760

761

762

763

764

765

766

767

768

769

770

771

772

773

774

775

776

11 Balke, T., Stock, M., Jensen, K., Bouma, T. J. \& Kleyer, M. A global analysis of the seaward salt marsh extent: The importance of tidal range. Water Resources Research 52, 3775-3786 (2016).

12 Rodríguez, J. F., Saco, P. M., Sandi, S., Saintilan, N. \& Riccardi, G. Potential increase in coastal wetland vulnerability to sea-level rise suggested by considering hydrodynamic attenuation effects. Nature communications 8, 1-12 (2017).

13 Dendy, S., Austermann, J., Creveling, J. \& Mitrovica, J. Sensitivity of Last Interglacial sea-level high stands to ice sheet configuration during Marine Isotope Stage 6. Quaternary Science Reviews 171, 234-244 (2017).

14 Argus, D. F., Peltier, W., Drummond, R. \& Moore, A. W. The Antarctica component of postglacial rebound model ICE-6G_C (VM5a) based on GPS positioning, exposure age dating of ice thicknesses, and relative sea level histories. Geophysical Journal International 198, 537-563 (2014).

15 Peltier, W. R., Argus, D. \& Drummond, R. Space geodesy constrains ice age terminal deglaciation: The global ICE-6G_C (VM5a) model. Journal of Geophysical Research: Solid Earth 120, 450-487 (2015).

16 Kendall, R. A., Mitrovica, J. X. \& Milne, G. A. On post-glacial sea level-II. Numerical formulation and comparative results on spherically symmetric models. Geophysical Journal International 161, 679-706 (2005).

17 Dziewonski, A. M. \& Anderson, D. L. Preliminary reference Earth model. Physics of the earth and planetary interiors 25, 297-356 (1981).

18 Liu, Z., Fagherazzi, S. \& Cui, B. Success of coastal wetlands restoration is driven by sediment availability. Communications Earth \& Environment 2, 1-9 (2021).

19 Schuerch, M. et al. Future response of global coastal wetlands to sea-level rise. Nature 561, 231-234 (2018).

20 Doerffer, R., Sorensen, K. \& Aiken, J. MERIS potential for coastal zone applications. International Journal of Remote Sensing 20, 1809-1818 (1999).

21 Wang, H. et al. Determining the spatial variability of wetland soil bulk density, organic matter, and the conversion factor between organic matter and organic carbon across coastal Louisiana, USA. Journal of Coastal Research 33, 507-517 (2017).

22 Dalrymple, R. W., Zaitlin, B. A. \& Boyd, R. Estuarine facies models; conceptual basis and stratigraphic implications. Journal of Sedimentary Research 62, 1130-1146 (1992).

23 Ganju, N. K. et al. Spatially integrative metrics reveal hidden vulnerability of microtidal salt marshes. Nature communications 8, 1-7 (2017).

24 Ganju, N. K., Defne, Z. \& Fagherazzi, S. Are elevation and open-water conversion of salt marshes connected? Geophysical Research Letters 47, e2019GL086703 (2020).

25 Wasson, K. et al. Understanding tidal marsh trajectories: evaluation of multiple indicators of marsh persistence. Environmental Research Letters 14, 124073 (2019).

26 Breiman, L. Random forests. Machine learning 45, 5-32 (2001).

27 Team, R. C. R: A language and environment for statistical computing. , 2020).

28 Garnier, S., Ross, N., Rudis, B., Sciaini, M. \& Scherer, C. viridis: Default color maps from 'matplotlib'. R package version 0.5. 1. CRAN: the Comprehensive R Archive Network. [Google Scholar] (2018).

29 Liaw, A. \& Wiener, M. Classification and regression by randomForest. $R$ news 2, 18$22(2002)$. 
Supplementary Figures and Tables

778

779

780

Data S1: SET-MH elevation change, accretion and ancillary data. (Excel File)

Table S1: Identifiers and Variables used in the analysis (Data S1).

\begin{tabular}{|c|c|}
\hline site.SET.identifier & Unique SET station ID used for linking all other data \\
\hline network & Geographic clusters of SETs \\
\hline country & Country within which SET is situated \\
\hline site.label & Site name for SET or replicate SETs \\
\hline latitude & Decimal degrees \\
\hline longitude & Decimal degrees \\
\hline TSM.2011 & MERIS-derived total suspended matter -average \\
\hline SLR & 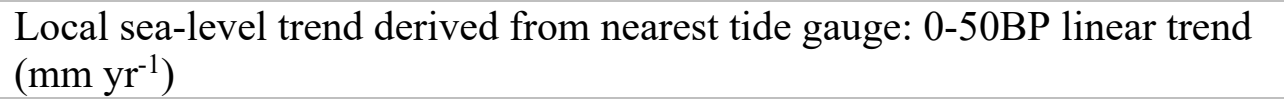 \\
\hline MHW & Mean High Water: datum consistent with marsh elevation (m) \\
\hline MLW & Mean Low Water: datum consistent with marsh elevation (m) \\
\hline MSL & Mean Sea Level: datum consistent with marsh elevation (m) \\
\hline marshElevation & Elevation of the SET in relation to local datum (m) \\
\hline $\mathrm{D}$ & Dimensionless D, see Methods for equation \\
\hline bulkDensity & Bulk density of the upper $10 \mathrm{~cm}\left(\right.$ dry, $g$ per $\left.\mathrm{cm}^{3}\right)$ \\
\hline $\mathrm{NEC}$ & Normalised Elevation Capital, see methods for equation \\
\hline $\operatorname{maxTemp}$ & Average daily maximum temperature (degrees Celsius) \\
\hline rainfall & Average annual rainfall $(\mathrm{mm})$ \\
\hline accretion & Rate of accretion above the feldspar horizon $\left(\mathrm{mm} \mathrm{yr}^{-1}\right)$ \\
\hline elevCapital & Elevation of SET in relation to modelled lowest marsh limits $(\mathrm{cm})$ \\
\hline posTidalFrame & Elevation in relation to the difference between MHW and MLW (m) \\
\hline elevation.rate & Rate of elevation gain from the SET record $\left(\mathrm{mm} \mathrm{yr}^{-1}\right)$ \\
\hline R2.SET & $\mathrm{R}^{2}$ of the linear trend in elevation through time \\
\hline years & Years of record for the SET readings \\
\hline startDate & Initial SET reading \\
\hline endDate & Final SET reading \\
\hline tidal.range & Difference between MHW and MLW (m) \\
\hline Spartina & Spartina dominant, binary \\
\hline shortGrassesHerbs & $\begin{array}{l}\text { dominated by short grasses and herbs (Sporobolus, Distichlis, Salicornia, } \\
\text { Sarcocornia, Poa, Glaux, Borrichia, Puccinellia, Paspalum, Elymus, } \\
\text { Impatiens), binary }\end{array}$ \\
\hline brackishRushes & $\begin{array}{l}\text { dominated by brackish rushes (Juncus, Schoenoplectus, Phragmites, } \\
\text { Cladium, Scirpus, Carex) }\end{array}$ \\
\hline saltbushes & dominated by saltbushes or shrubs (Atriplex, Tecticornia, Avicennia) \\
\hline category & Vegetation structural category \\
\hline SLR250 & Sea level trend 0 - 500 BP (from Glacio-isostatic modelling) $\left(\mathrm{mm} \mathrm{yr}^{-1}\right)$ \\
\hline SLR750 & Sea level trend 500 - 1000 BP (from Glacio-isostatic modelling) $\left(\mathrm{mm} \mathrm{yr}^{-1}\right)$ \\
\hline SLR1250 & Sea level trend 1000 - 1500 BP (from Glacio-isostatic modelling) $\left(\mathrm{mm} \mathrm{yr}^{-1}\right)$ \\
\hline SLR1750 & Sea level trend 1500 - $2000 \mathrm{BP}$ (from Glacio-isostatic modelling) $\left(\mathrm{mm} \mathrm{yr}^{-1}\right)$ \\
\hline SLR2250 & Sea level trend 2000 - $2500 \mathrm{BP}$ (from Glacio-isostatic modelling) $\left(\mathrm{mm} \mathrm{yr}^{-1}\right)$ \\
\hline
\end{tabular}


SLR2750

SLR3250

SLR3750

Geomorphic.setting

Shore.R2

Shore.rate

Shore.Dist

UVVR

RSLR.period.of.measure

elevDeficit
Sea level trend 2500 - 3000 BP (from Glacio-isostatic modelling) $\left(\mathrm{mm} \mathrm{yr}^{-1}\right.$ )

Sea level trend 3000 - 3500 BP (from Glacio-isostatic modelling) $\left(\mathrm{mm} \mathrm{yr}^{-1}\right)$

Sea level trend 3500 - 4000 BP (from Glacio-isostatic modelling) $\left(\mathrm{mm} \mathrm{yr}^{-1}\right.$ )

River deltaic, Tide Dominant, barrierLagoon, Barrier estuary, Embayment, Drowned River Valley

$\mathrm{R}^{2}$ of shoreline rate of change

rate of shoreline retreat $\mathrm{m} \mathrm{yr}^{-1}$

distance to shoreline (m)

unvegetated-to-vegetated ratio

RSLR for each site for the period of SET measurement. Linear trend ( $\mathrm{mm}$ $\mathrm{yr}^{-1}$ )

Elevation Deficit, defined as RSLR.period.of.measure minus elevation.rate. $\left(\mathrm{mm} \mathrm{yr}^{-1}\right)$ 
823 Table S2: Sources of meteorological and sea-level data included in Data S1

\begin{tabular}{|c|c|c|c|}
\hline Region & Climate Data & Tidal Data & RSL trend $0-50$ \\
\hline United States & $\begin{array}{l}\text { https://www.ncdc.noaa.gov/cdo- } \\
\text { web/datatools/normals }\end{array}$ & $\begin{array}{l}\text { https://tidesandcurrents.noaa.go } \\
\text { v/map/index.html?type=TidePred } \\
\text { ictions\&region= }\end{array}$ & $\begin{array}{l}\text { https://tidesandcurrents.noaa.g } \\
\text { ov/sltrends/sltrends.html }\end{array}$ \\
\hline United Kingdom & $\begin{array}{l}\text { https://www.metoffice.gov.uk/re } \\
\text { search/climate/maps-and- } \\
\text { data/uk-climate-averages }\end{array}$ & $\begin{array}{l}\text { https://www.ntslf.org/data/uk- } \\
\text { network-real-time }\end{array}$ & $\begin{array}{l}\text { https://tidesandcurrents.noaa.g } \\
\text { ov/sltrends/sltrends.html }\end{array}$ \\
\hline Canada & $\begin{array}{l}\text { https://climate.weather.gc.ca/cli } \\
\text { mate_normals/ }\end{array}$ & $\begin{array}{l}\text { https://protect- } \\
\text { au.mimecast.com/s/4wJnCE8wIR } \\
\text { CKAKNMSNvEdI?domain=meds- } \\
\text { sdmm.dfo-mpo.gc.ca }\end{array}$ & $\begin{array}{l}\text { https://tidesandcurrents.noaa.g } \\
\text { ov/sltrends/sltrends.html }\end{array}$ \\
\hline Spain & $\begin{array}{l}\text { https://en.climate- } \\
\text { data.org/europe/spain/catalonia/ } \\
\text { deltebre-768271/ }\end{array}$ & & $\begin{array}{l}\text { https://tidesandcurrents.noaa.g } \\
\text { ov/sltrends/sltrends.html } \\
\text { Marrasé, C., Camí, J., \& } \\
\text { Peters, F. (2020). Report on } \\
\text { climate change and health in } \\
\text { Catalonia: Informe de la } \\
\text { Secció de Ciències } \\
\text { Biològiques de l'Institut } \\
\text { d'Estudis Catalans }\end{array}$ \\
\hline Australia & $\begin{array}{l}\text { http://www.bom.gov.au/climate/ } \\
\text { data/index }\end{array}$ & 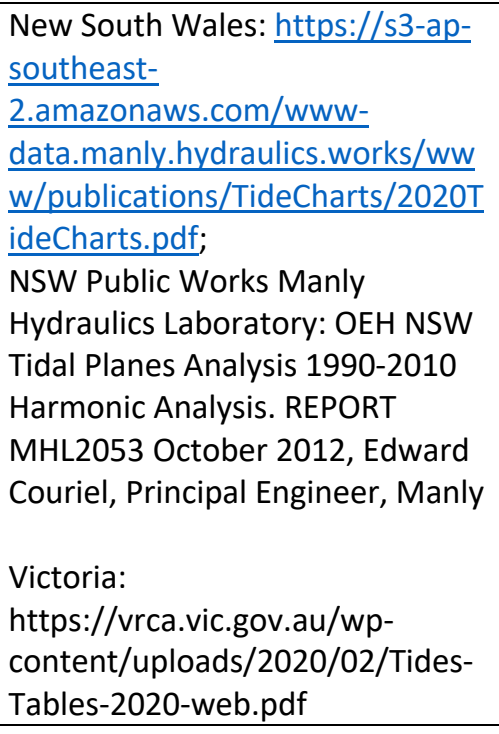 & $\begin{array}{l}\text { https://tidesandcurrents.noaa.g } \\
\text { ov/sltrends/sltrends.html } \\
\text { http://www.bom.gov.au/ocean } \\
\text { ography/projects/abslmp/data/ } \\
\text { monthly.shtml (Port Kembla, } \\
\underline{\text { Stony Point) }}\end{array}$ \\
\hline South Africa & & $\begin{array}{l}\text { Pereyra Lago, R. (1993). Tidal } \\
\text { exchange of larvae of Sesarma } \\
\text { catenata (Decapoda, Brachyura) } \\
\text { in the Swartkops estuary, South } \\
\text { Africa. South African Journal of } \\
\text { Zoology, 28(4), 182-191. } \\
\text { Maree, B. (2000). Structure } \\
\text { and status of the intertidal } \\
\text { wetlands of the Knysna } \\
\text { Estuary. Transactions of the } \\
\text { Royal Society of South } \\
\text { Africa, 55(2), 163-176. }\end{array}$ & $\begin{array}{l}\text { https://tidesandcurrents.noaa.g } \\
\text { ov/sltrends/sltrends.html }\end{array}$ \\
\hline
\end{tabular}


828

829

830

831

832

833

834

835

836

837

838

839

840

841

842

843

844

845

846

847

848

849

850

851

852

853

854

855

856

857

858

859

860

861

862

863

864

865

866

867

868

869

870

871

Table S3: Rates of elevation gain in $\mathrm{mm} \mathrm{yr}^{-1}$ and accretion in $\mathrm{mm} \mathrm{yr}^{-1}$ (standard deviation) in relation to position in tidal frame and shoreline trends.

\begin{tabular}{|l|l|l|l|l|l|}
\hline & $\begin{array}{l}\text { Global } \\
\text { average }\end{array}$ & \multicolumn{2}{|c|}{ Low Marsh $(\mathrm{D}>0)$} & \multicolumn{2}{c|}{ High Marsh $\mathrm{D}<0$} \\
\hline & & Advance $(\mathrm{n}=37)$ & $\begin{array}{l}\text { Retreat } \\
(\mathrm{n}=138)\end{array}$ & $\begin{array}{l}\text { Advance } \\
(\mathrm{n}=79)\end{array}$ & Retreat $(\mathrm{n}=137)$ \\
\hline Elevation trend & $2.97(3.85)$ & $3.23(3.17)^{\mathrm{ab}}$ & $4.71(5.10)^{\mathrm{a}}$ & $1.93(2.83)^{\mathrm{b}}$ & $1.82(2.19)^{\mathrm{b}}$ \\
\hline Accretion & $5.69(5.57)$ & $6.87(3.74)^{\mathrm{a}}$ & $9.53(6.94)^{\mathrm{a}}$ & $2.78(2.35)^{\mathrm{b}}$ & $2.83(1.89)^{\mathrm{b}}$ \\
\hline
\end{tabular}


872

\begin{tabular}{|l|l|l|l|l|}
\hline Elevation rate & $\mathrm{n}$ & $\begin{array}{l}\text { Distance to } \\
\text { shore } \\
\text { Mean, (s.d.) }\end{array}$ & $\begin{array}{l}\text { Elevation } \\
\text { failure } \\
\text { (median years) }\end{array}$ & $\begin{array}{l}\text { Retreat failure } \\
\text { (median years) }\end{array}$ \\
\hline$>7 \mathrm{~mm} \mathrm{yr}^{-1}$ & 51 & $69.5(351.9)$ & 3.7 & 109.2 \\
\hline $3.5-7 \mathrm{~mm} \mathrm{yr}^{-1}$ & 97 & $128.6(417.4)$ & 90.4 & 127.2 \\
\hline $1.5-3.5 \mathrm{~mm} \mathrm{yr}^{-1}$ & 97 & $109.7(155.5)$ & 327.6 & 623.7 \\
\hline $0-1.5 \mathrm{~mm} \mathrm{yr}^{-1}$ & 92 & $202.5(364.9)$ & 440.2 & 939.9 \\
\hline$<0 \mathrm{~mm} \mathrm{yr}^{-1}$ & 52 & $478.0(1244.5)$ & 323.1 & 836.0 \\
\hline
\end{tabular}

Table S4: Median projected time to failure at the point of the SET, calculated as the time taken to reach minimum survival elevation under the current elevation deficit (elevation failure), and the time taken to erode the SET under current rates of retreat (retreat failure). Note that the median projected survival time is lower under higher rates of elevation gain. $<0$ 
911 Fig S1: The relative importance of variables contributing to models of marsh vertical 912 accretion at global scales, based on Random Forests analyses. The total percentage of 913 variation explained by the model is included in plot title.

914 Variables used as explained in Table S1 (from Data S1) include TSM.2011, SLR50,

915 marshElevation, D, bulkDensity, maxTemp, rainfall, tidal.range, Spartina,

916 shortGrassesHerbs, brackishRushes, saltbushes, category, SLR250, SLR3750,

917 Geomorphic.setting, Shore.rate, Shore.Dist, UVVR

919

Global accretion variance explained $71 \%$

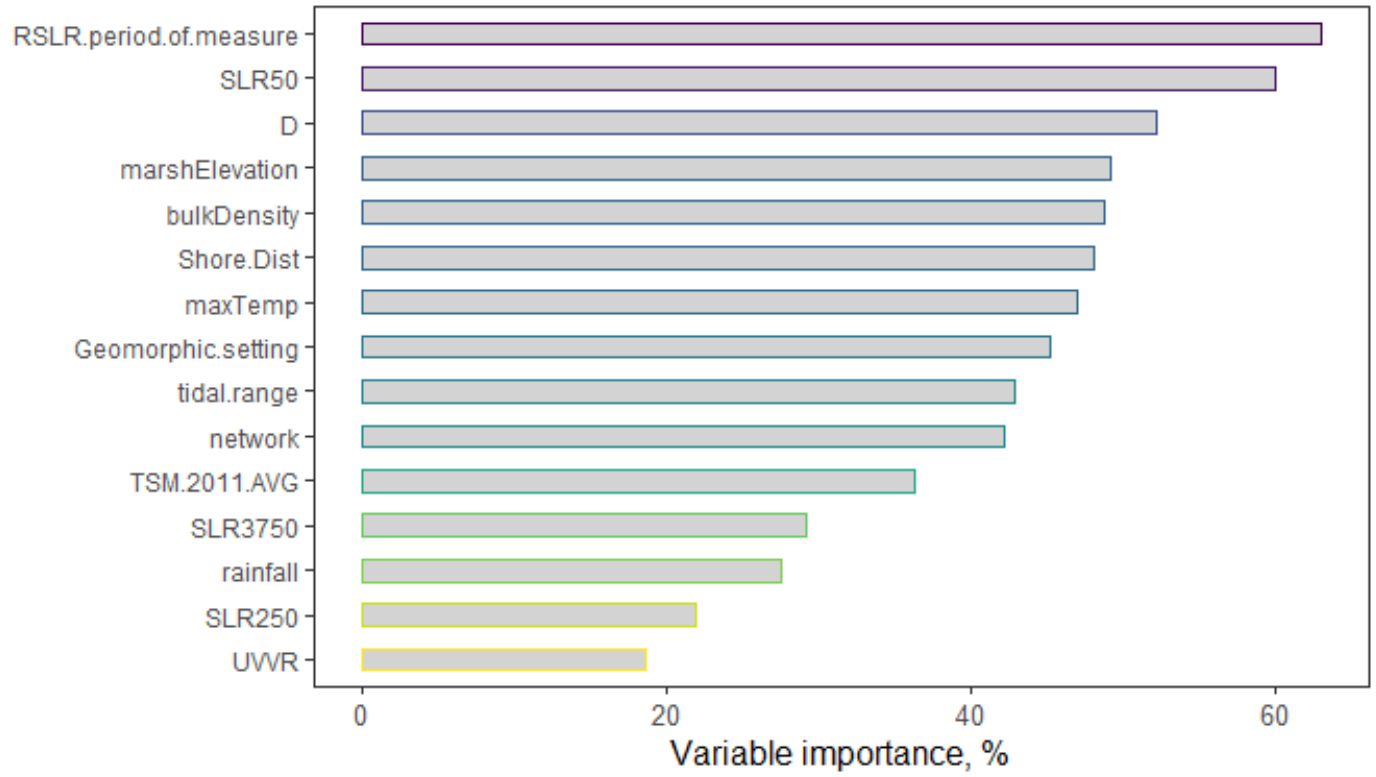


944 Fig S2: The relative importance of variables contributing to models of marsh surface 945 elevation at global scales, based on Random Forests analyses. The total percentage of 946 variation explained by the model is included in plot title.

947 Variables used as explained in Table S1 (from Data S1) include TSM.2011, SLR50, 948 marshElevation, D, bulkDensity, maxTemp, rainfall, tidal.range, Spartina, 949 shortGrassesHerbs, brackishRushes, saltbushes, category, SLR250, SLR3750, 950 Geomorphic.setting, Shore.rate, Shore.Dist, UVVR

Global elevation variance explained $45 \%$

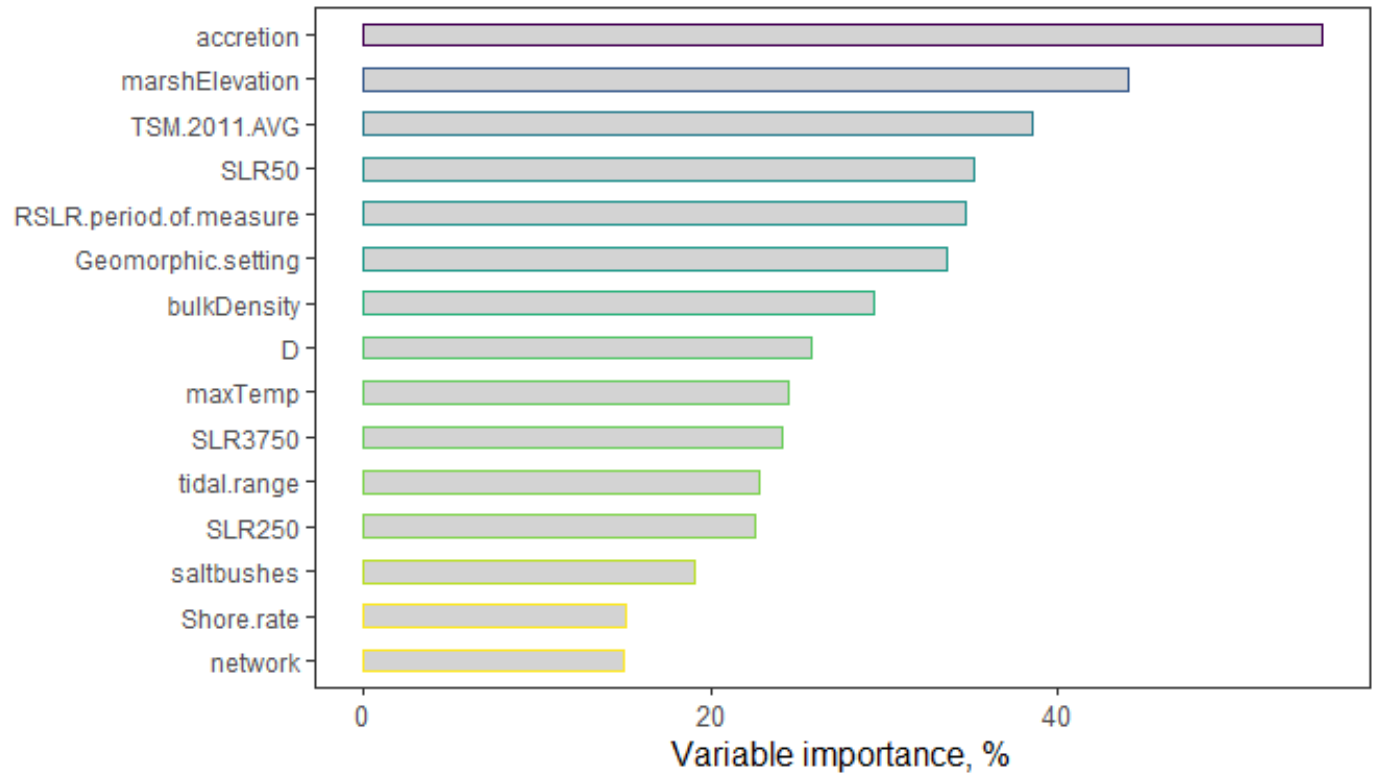


978 Fig S3: Frequency distribution of rates of elevation gain for High Marshes $(\mathrm{D}<0)$ and Low 979 Marshes $(\mathrm{D}>0)$ including whether shorelines are advancing or retreating

980

981

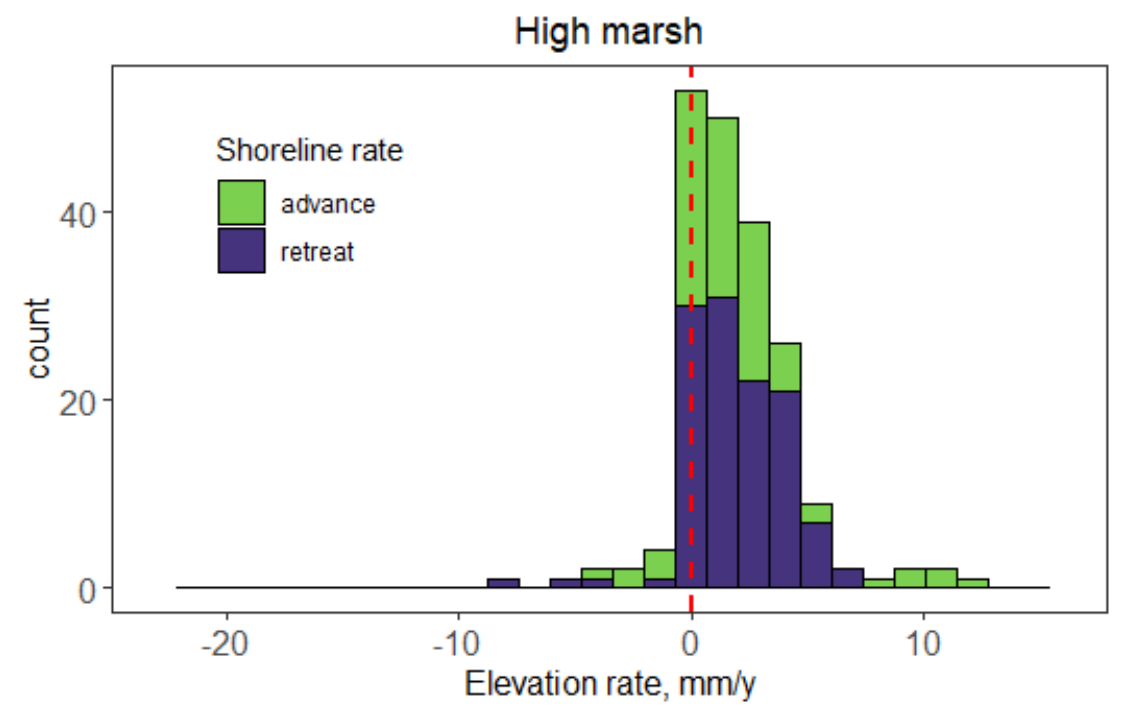

982

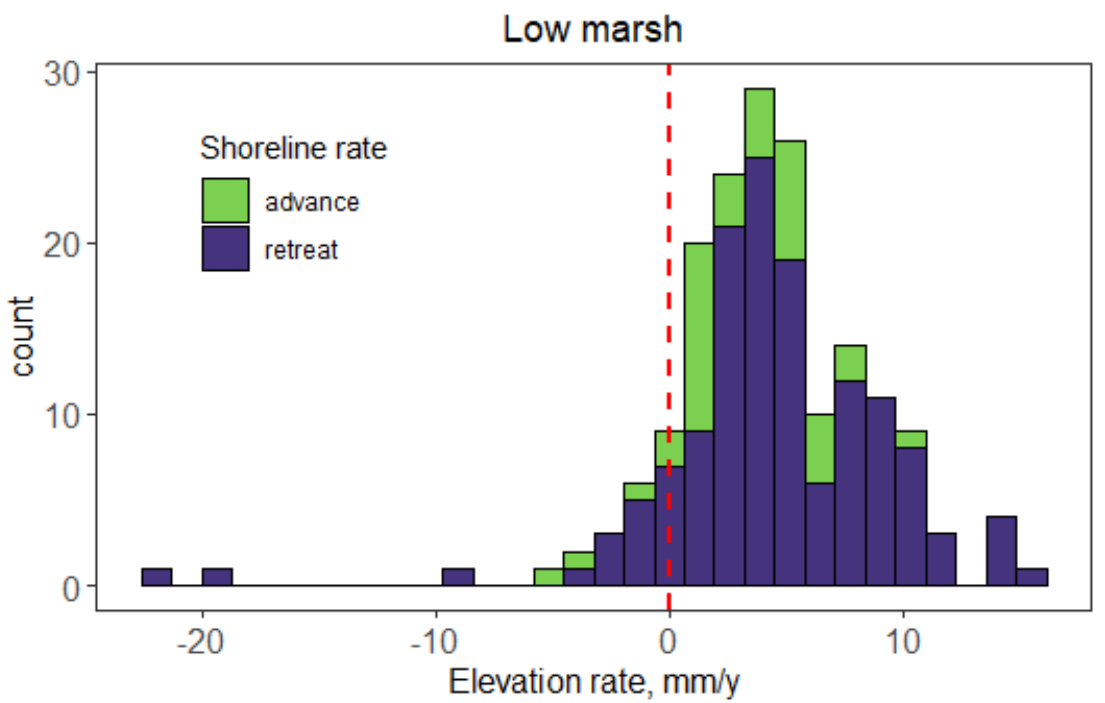


998 Figure S4: Two SET-MH stations subject to erosion during the measurement period,

999 illustrating the short-term increase in elevation gain prior to failure. Data retrieved from the 1000 Coastal Information Management System (CIMS) database (http://cims.coastal.louisiana.gov) 1001 with images from Google Earth.

1002
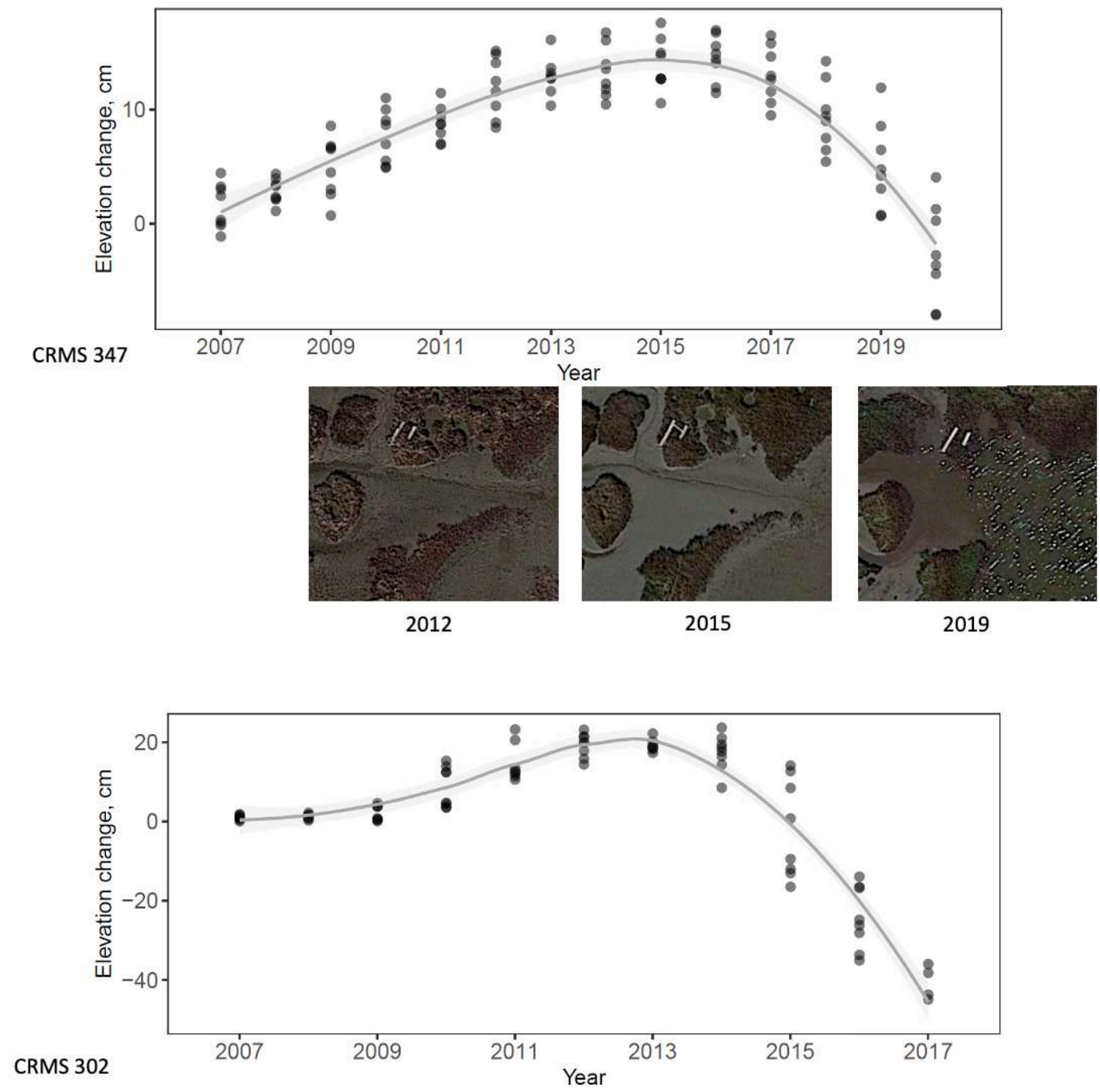

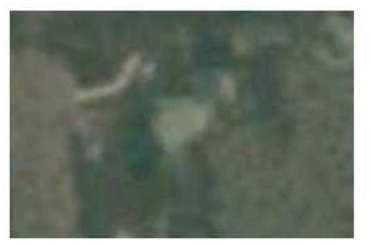

2007

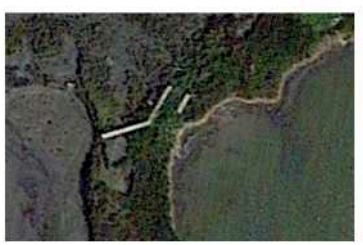

2012

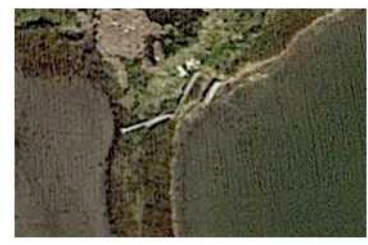

2014

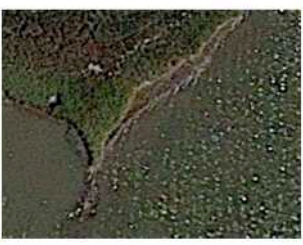

2019 


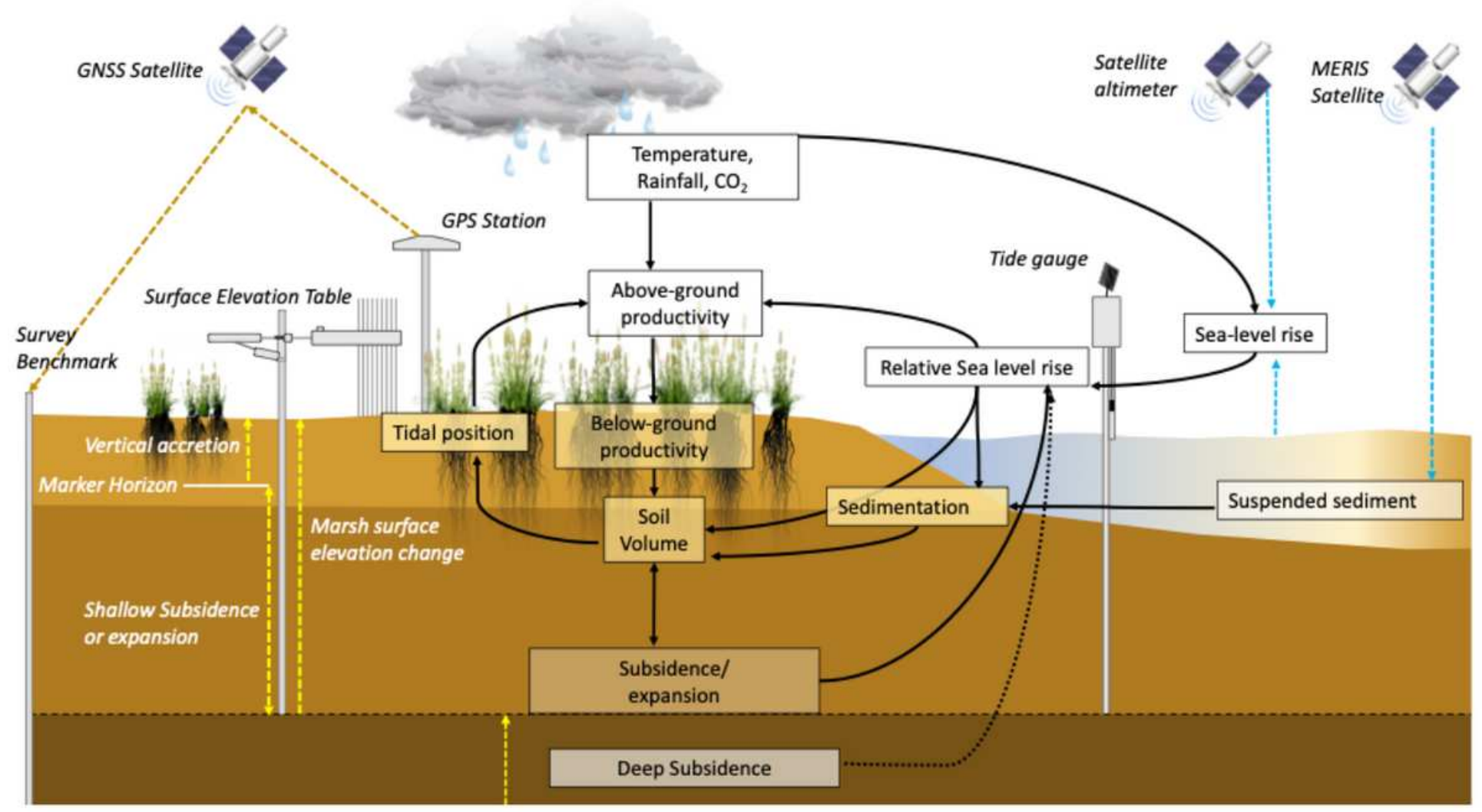

\section{Figure 1}

Processes influencing marsh surface elevation and their measurement in the SET- MH monitoring network. 

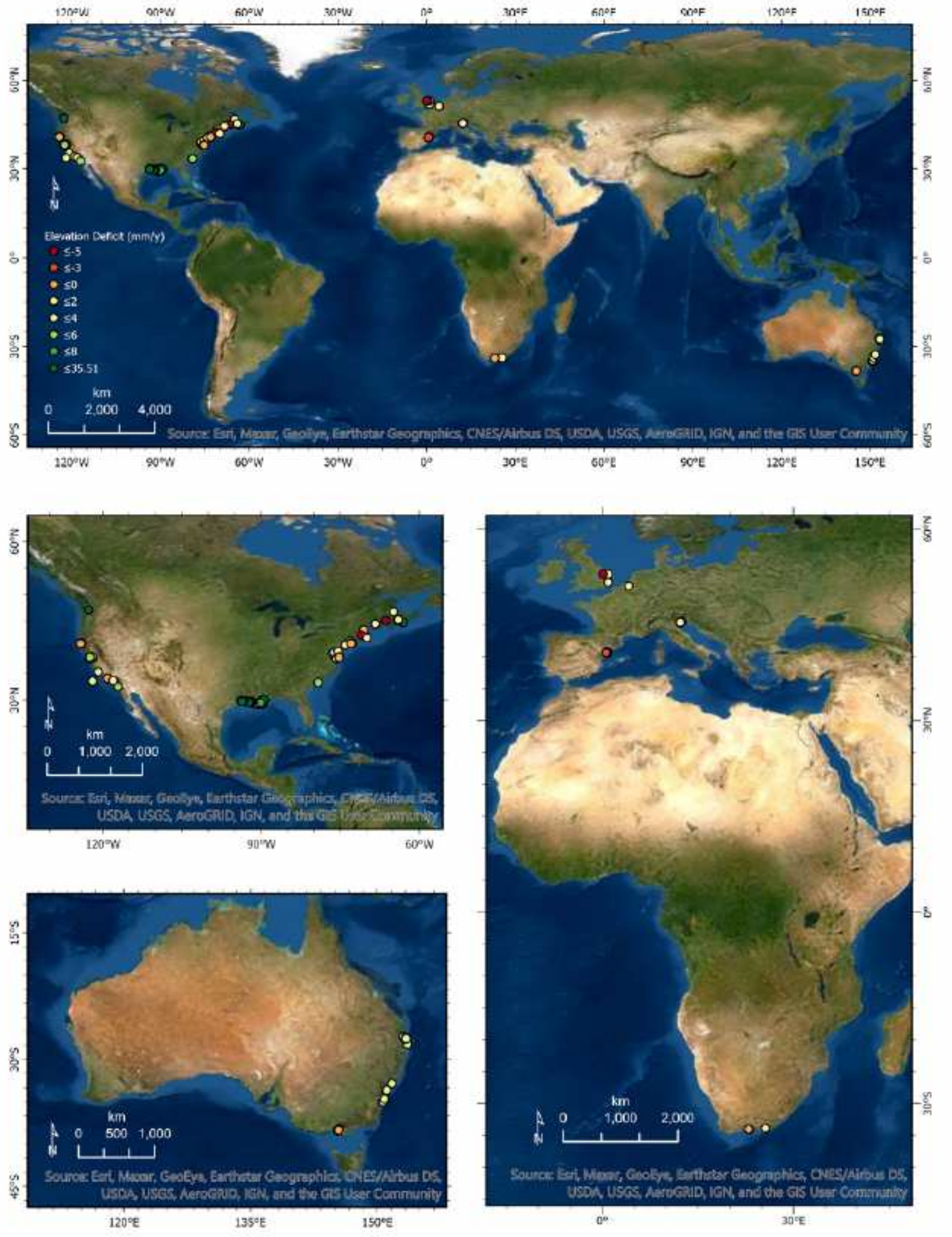

\section{Figure 2}

Distribution of tidal marsh SET-MH stations used in the analysis, and deficit between elevation gain and local RSLR. Note: The designations employed and the presentation of the material on this map do not imply the expression of any opinion whatsoever on the part of Research Square concerning the legal status of any country, territory, city or area or of its authorities, or concerning the delimitation of its frontiers or boundaries. This map has been provided by the authors. 

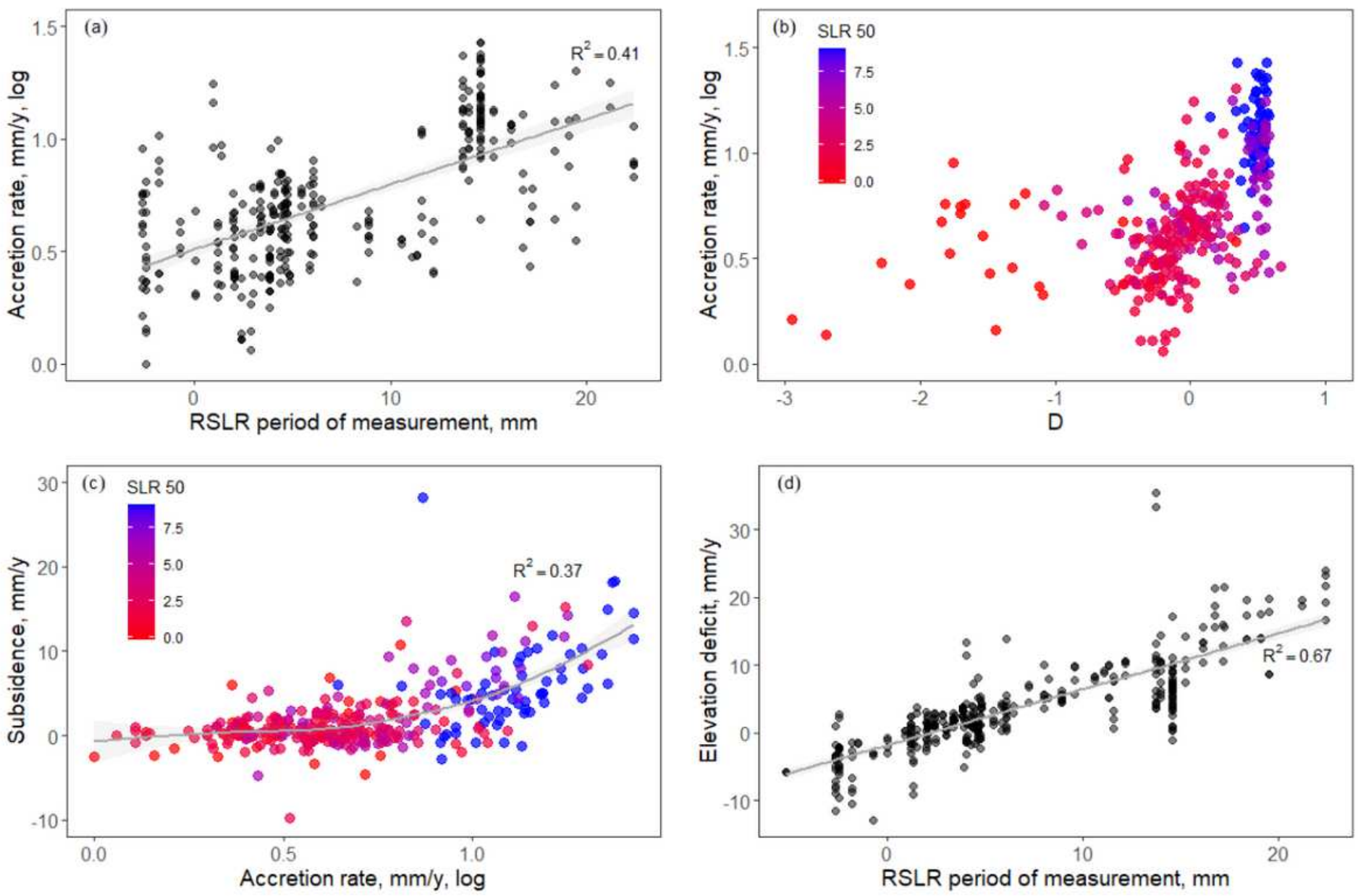

Figure 3

The increasing vulnerability of tidal marshes to RSLR. While accretion increases with RSLR over the same period of measurement (a), and with increasing depth in the tidal plane (b), the rate of shallow marsh subsidence increases with accretion rate (with an upward inflexion as RSLR rises above $\sim 7 \mathrm{~mm}$ yr-1 (c). As a result, the deficit between elevation gain and RSLR increases with RSLR (d). In panels (b) and (c) points are coloured for the 50-year RSLR trend in $\mathrm{mm}$ yr-1 